\title{
Calciothermic powders of rare metals and intermetallic compounds
}

\author{
A. V. Kasimtsev, CEO ${ }^{1}$, e-mail: metsintez@yandex.ru \\ Yu. V. Levinsky, Leading Researcher, Laboratory of Physical Stimulation of Physico-Chemical Processes², \\ e-mail: levinsky35@mail.ru \\ S. N. Yudin, Head of Technological Bureau' , e-mail: Sergey-USN@mail.ru \\ ${ }^{1}$ LTD Metsintez, Tula, Russia. \\ ${ }^{2}$ Merzhanov Institute of Structural Macrokinetics and Materials Science of Russian Academy of Sciences, Chernogolovka, \\ Russia.
}

\begin{abstract}
This paper presents a profound review of scientific and technical literature on the issues of calciothermic production of powders of rare metals, intermetallic compounds, composite materials and refractory oxygen-free compounds (carbides, nitrides). Calciothermic reduction is a metallothermic synthesis method for those substances where calcium or its derivatives, such as calcium hydride or calcium carbide, are used as a reducing agent.

Thermodynamics aspects of a reduction process are covered in the paper broadly, with particular emphasis on assessing the reduction depth of original oxide raw materials, $\mathrm{as}^{\mathrm{TiO}}{ }_{2}$. The mechanism and kinetics of calciothermic synthesis of single-component and multi-component alloys are described. Presented are both technological means of obtaining materials and hardware resources of many varieties of calciothermic method.

The key features of the work are generalization and systematization of properties (chemical, physical, technological) of materials synthesized by calciothermic method. The data are accumulated in the appropriate tables and divided by substance classes (powders of metals and alloys, powders of intermetallic compounds, powders of carbides, powders of nitrides, and powders of composite materials). Methods of calciothermic powder making in case of the singlecomponent and complex multi-component systems are briefly described.

This work will be interesting to the students of metallurgical profile and specialists whose scientific interests are in the field of material synthesis by methods of powder metallurgy.

Key words: calcium thermal reduction, calcium hydride method, powder metallurgy, intermetallic compounds, powders of metals and alloys, properties, synthesis, literature review.

DOI: $10.17580 / \mathrm{nfm} .2020 .02 .05$
\end{abstract}

\section{Introduction}

$\mathrm{C}$ alcium thermal reduction is a metallothermic process of reduction of metals from their oxides, halogenides and other compounds. Among other reducing agents, calcium has the greatest affinity for oxygen and halogens. However, owing to high cost it would be appropriate to be used only for the production of chromium, rare earth metals (REM), some rare metals, uranium, thorium and their alloys.

The research of calciothermic oxide reduction originated in the middle of the last century in the works by W. J. Kroll [1-2], who obtained titanium powder by calcium reduction of its oxide.

Currently, different technological options of a reduction process are based on different original substances containing reduced metals and calcium, as well as auxiliary substances, which accelerate the process, lower its temperature, or lead to getting the improved economic or environmental indicators. Each of these options is characterized by its own, individual set of chemical processes and their proceeding conditions.

The list of calciothermic recovery methods, their abbreviation and brief description are given below:

- Kroll method [1-3]. Direct calcium reduction of oxides. The process is prolonged and relatively expensive.
- Calcium hydride reduction of metal oxides with calcium hydride [4-5].

- FFC method (Frau, Fartin and Chen). Reduction of metal oxides using electrolysis in a molten $\mathrm{CaCl}_{2}$ medium in a bath with graphite anode [6-10].

- OS method (Ono and Suzuki). A combination of calciothermic and electrochemical processes with electrolysis in a $\mathrm{CaO}-\mathrm{CaCl}_{2}$ melt at $900{ }^{\circ} \mathrm{C}$ [9-10].

- EMR, ESR, USTB, EMRIMSE methods. Modifications of electrolytic reduction in molten salts [9-11].

- PRP method (Preform Reduction Process). Steam from a Ca melt into $\mathrm{CaCl}_{2}$ is let pass through the tablets pressed from $\mathrm{TiO}_{2}$ powder, where titanium dioxide is reduced [12].

- Okabe methods (Okabe T. H.); Xu method (Xu B.-Q.). A variation of the PRP method for reducing $\mathrm{TiO}_{2}$ powder using $\mathrm{Ca}$ vapors passing through the samples pre-pressed from $\mathrm{TiO}_{2}$ powder [12-14].

- CRD method (Calciothermic Reduction-Diffusion); RD method (Reduction-Diffusion Process). The method is used mainly for the production of powders of alloys and intermetallic compounds. In the Ca melt, there are particles of oxides of the reduced metal, whose atoms diffuse from the melt to the alloying element particles, then they diffuse into alloys or intermetallic compounds [15-31]. 


\section{Thermodynamics of reduction processes}

The variety of phenomena that occur during calcium reduction of oxides and other metal compounds determines a wide range of chemical processes going on as this take place.

Each of the reduction methods listed above represents different sets of such processes. In this connection, it is well to consider not the thermodynamics of the reduction method itself, but the thermodynamics of individual processes that make it up. Above all, these processes include an interaction of metal oxides with calcium (with no presence of other chemical elements in the system); an interaction of metal oxides with calcium and calcium hydride (calcium hydride reduction); an interaction of metal oxides with calcium in the presence of calcium chloride.

\subsection{Thermodynamics of calcium reduction of metal oxides}

The thermodynamics of these processes is determined by equilibrium in $\mathrm{Me}-\mathrm{Ca}-\mathrm{O}$ systems, where $\mathrm{Me}$ is the metal being reduced. A feature of such systems is the presence of oxygen in them. If activities of pure $\mathrm{Me}$ and $\mathrm{Ca}$ in the condensed form are assumed equal to 1, then the gaseous oxygen activity is determined by its partial pressure. Therefore, the isothermal sections of equilibrium ternary phase diagrams of the systems will have different appearance at different values of oxygen partial pressure.

The use of ternary phase diagrams of $\mathrm{Me}-\mathrm{Ca}-\mathrm{O}$ system for analyzing calciothermic reduction is convenient to consider by the example of the most studied $\mathrm{Ti}-\mathrm{Ca}-\mathrm{O}$ system. An isothermal cross-section of this diagram at a temperature of $927^{\circ} \mathrm{C}$ is shown in Fig. 1.

The diagrams in Fig. 1 illustrate complicated nature of phase equilibriums in this system. In the oxygen corner of the diagram, there is placed gaseous oxygen in the standard state $p_{\mathrm{O}_{2}}=1 \mathrm{~atm}\left(101 \mathrm{kPa}, a_{\mathrm{O}}=1\right)$. This pressure remains

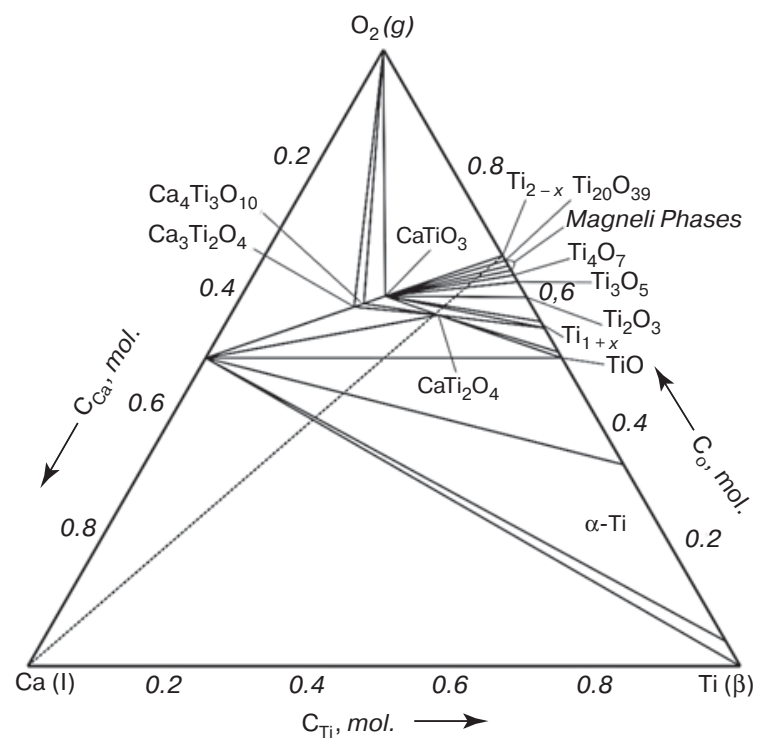

Fig. 1. Isothermal cross-section of a phase diagram of $\mathrm{Ca}-\mathrm{Ti}-\mathrm{O}$ system at a temperature of $927^{\circ} \mathrm{C}$ constant up to the boundary with $\mathrm{CaO}, \mathrm{CaTiO}_{3}$ and $\mathrm{TiO}_{2}$ oxygen-saturated phases. In titanium condensed phases, the amount of oxygen is determined by the concentration scale, and oxygen activity $a_{\mathrm{O}}$ as well as its partial pressure $p_{\mathrm{O}_{2}}$ decrease in discrete steps at the phase boundaries up to $a_{\mathrm{O}}=0$ at $p_{\mathrm{O}_{2}}=0$ in the metal corners of the diagram.

According to Fig. 1, the $\mathrm{Ca}-\mathrm{TiO}_{2}$ cross-section is not pseudobinary. When original mixture contains $x_{\mathrm{Ca}} \geq 0.6$, $\mathrm{CaO}$ and $\mathrm{Ti}$ phases will be in equilibrium.

The $\mathrm{Ca}-\mathrm{TiO}_{2}$ cross-section shows which phases can be in equilibrium when original mixture contains $x_{\mathrm{Ca}}<0.6$. List of the phases that are in a two-phase equilibrium as the calcium content decreases in the area $0.6<x_{\mathrm{Ca}}<1.0$ is presented in Table 1.

The $\mathrm{Ca}-\mathrm{TiO}_{2}$ cross-section shown as a dotted line in Fig. 1 points to the possibility of appearance of oxide and metal phases resulting from interaction of $\mathrm{TiO}_{2}$ solid particles with the calcium melt. However, neither number of these phases nor especially the rate of their formation during the interaction of $\mathrm{TiO}_{2}$ with $\mathrm{Ca}$ and the transition from the initial state to equilibrium may be judged from the order of their arrangement in Table 1.

The possibility of calcium reduction of oxides of other metals is illustrated in Table 2, in which an affinity of oxygen for different metals is represented [32].

From Table 2 it follows that calcium along with REM has the most affinity for oxygen.

Table 2 accumulates standard data at a temperature of $298 \mathrm{~K}$. The dependence of the Gibbs energy of formation on the temperature $\Delta G_{T}^{0}$ for some oxides [4].

In fact,

$$
\begin{aligned}
& \Delta G_{298}^{0}=\Delta H_{298}^{0}-298 \cdot \Delta S_{298}^{0}, \\
& \Delta G_{T}^{0}=\Delta H_{T}^{0}-T \Delta S_{T}^{0}=\Delta H_{298}^{0}-T \Delta S_{298}^{0}+ \\
& +\int_{298}^{T} \Delta C_{p}^{0} d T-\int_{298}^{T} \Delta C_{p}^{0} d T / T,
\end{aligned}
$$

where $\Delta G_{298}^{0}, \Delta H_{298}^{0}, \Delta S_{298}^{0}$ are the Gibbs energy, enthalpy

\begin{tabular}{|c|c|c|c|}
\hline $\begin{array}{l}\text { Point } \\
\text { No. }\end{array}$ & Equilibrium phases & $\begin{array}{l}\text { Point } \\
\text { No. }\end{array}$ & Equilibrium phases \\
\hline 1 & $\beta-\mathrm{Ti}+\mathrm{CaO}$ & 8 & $\mathrm{TiO}_{1+\mathrm{x}}+\mathrm{CaTiO}_{3}$ \\
\hline 2 & $\alpha-\mathrm{Ti}+\mathrm{CaO}$ & 9 & $\mathrm{Ti}_{2} \mathrm{O}_{3}+\mathrm{CaTiO}_{3}$ \\
\hline 3 & $\mathrm{TiO}+\mathrm{CaO}$ & 10 & $\mathrm{Ti}_{3} \mathrm{O}_{5}+\mathrm{CaTiO}_{3}$ \\
\hline 4 & $\mathrm{Ca}_{2} \mathrm{TiO}_{4}+\mathrm{CaO}$ & 11 & $\mathrm{Ti}_{4} \mathrm{O}_{7}+\mathrm{CaTiO}_{3}$ \\
\hline 5 & $\mathrm{Ca}_{2} \mathrm{TiO}_{4}+\mathrm{Ca}_{3} \mathrm{Ti}_{2} \mathrm{O}_{7}$ & 12 & Magnéli phases $+\mathrm{CaTiO}_{3}$ \\
\hline 6 & $\mathrm{Ca}_{2} \mathrm{TiO}_{4}+\mathrm{Ca}_{4} \mathrm{Ti}_{3} \mathrm{O}_{10}$ & 13 & $\mathrm{Ti}_{20} \mathrm{O}_{39}+\mathrm{CaTiO}_{3}$ \\
\hline 7 & $\mathrm{Ca}_{2} \mathrm{TiO}_{4}+\mathrm{CaTiO}_{3}$ & 14 & $\mathrm{TiO}_{2-x}+\mathrm{CaTiO}_{3}$ \\
\hline
\end{tabular}
and entropy at a temperature of $298 \mathrm{~K} ; \Delta C_{p}^{0}$ is a difference in the heat capacities of participants of the reactions. 
Table 2.

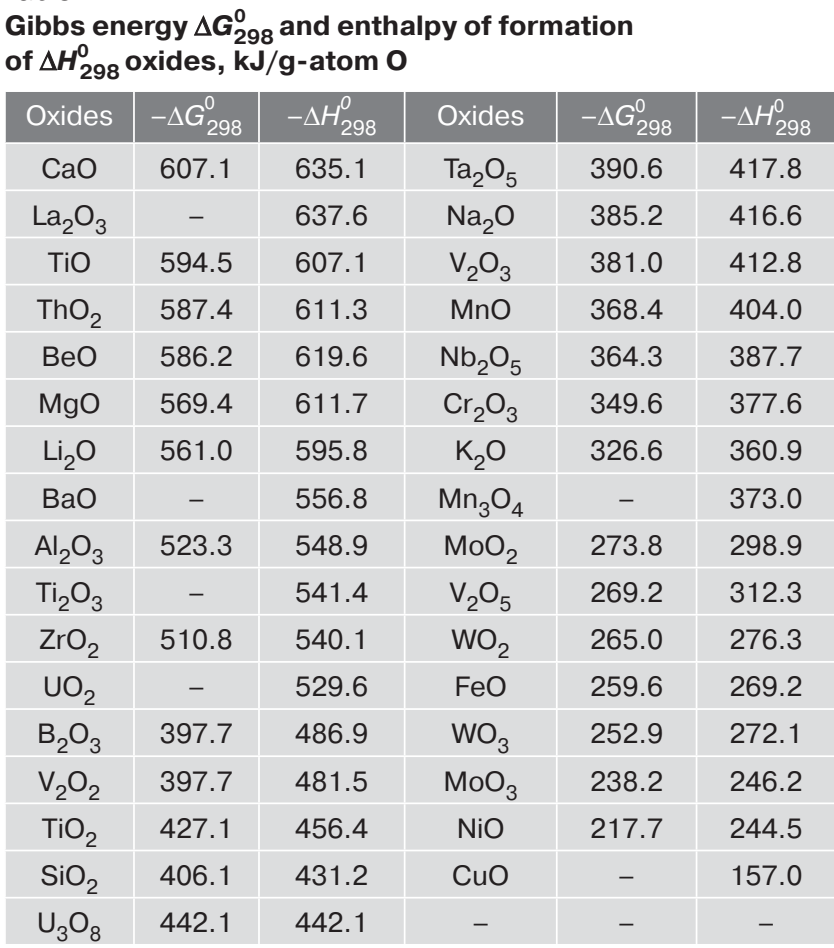

In all main overall reactions of metallothermy

$$
M e^{\mathrm{I}} \mathrm{O}+M e^{\mathrm{II}}=M e^{\mathrm{I}}+M e^{\mathrm{II}} \mathrm{O}
$$

all participants of the interaction are in a condensed state. Typical temperatures for metallothermic reactions are $800-1100{ }^{\circ} \mathrm{C}$. As a rule, these temperatures are higher than characteristic temperatures (Debye temperatures) for all participants of the reactions. Therefore the difference in the heat capacity of the left and right parts of the reaction (3) is close to zero and

$$
\int_{298}^{T} \Delta C_{p}^{0} d T-\int_{298}^{T} \Delta C_{p}^{0} d T / T \approx 0 .
$$

As a result of this, linear dependences $\Delta G^{0}(T)$ may be used for approximate technical computing without any special errors.

Much greater difficulties are encountered in thermodynamic calculations of metallothermic reactions, including the calciothermic ones, with the production of twoor more multicomponent final products - solid solutions or intermetallic compounds.

For this type of reaction:

$$
M e^{\mathrm{I}} \mathrm{O}+\mathrm{Ca}+M e^{\mathrm{II}}=M e^{\mathrm{I}} M e^{\mathrm{II}}+\mathrm{CaO},
$$

where $M e^{\mathrm{I}} M e^{\mathrm{II}}$ is a solid solution or intermetallic compound formed by metal $M e^{\mathrm{I}}$ and metal $M e^{\mathrm{II}}$.

The Gibbs energy of $M e^{\mathrm{I}} M e^{\mathrm{II}}$ formation contributes to the resulting change in the Gibbs energy of the reaction (5) besides the difference in the Gibbs energy between $\mathrm{CaO}$ and $M e^{\mathrm{I}} \mathrm{O}$.

From a practical point of view, reactions of type (5) are of special interest in the cases where $M e^{\mathrm{I}} \mathrm{O}$ oxide is found to be thermodynamically stronger than $\mathrm{CaO}$, that is, $M e^{\mathrm{I}} \mathrm{O}$ could not be reduced by calcium.

Calciothermic reduction of yttrium oxide, studied in [28], exemplifies this reaction:

$$
\mathrm{Y}_{2} \mathrm{O}_{3}+3 \mathrm{Ca}+4 \mathrm{Ni}=3 \mathrm{CaO}+2 \mathrm{YNi}_{2} \text {. }
$$

The Gibbs energy of this reaction calculated in view of $\mathrm{YNi}_{2}$ formation at temperatures of $950-1050{ }^{\circ} \mathrm{C}$, was significantly negative (from -367 to $-389 \mathrm{~kJ} / \mathrm{mol}$ ), that is, the possibility of $\mathrm{YNi}_{2}$ formation was confirmed, which was proved experimentally [28].

Thermodynamic calculations of the type (5) reactions become complicated by the need for availability of experimental data on thermodynamic functions of $M e^{\mathrm{I}} M e^{\mathrm{II}}$. These calculations are relatively simple if $M e^{\mathrm{I}} M e^{\mathrm{II}}$ represent phases of constant composition. Otherwise, it is necessary to know the activities of metals, their concentration and temperature dependences, especially when forming solid solutions based on one of the metals.

Given such dependences or at least their approximate estimation, it becomes possible to calculate critical values of $M e^{\mathrm{I}} M e^{\mathrm{II}}$ concentrations, at which calcium reduction of $M e^{\mathrm{I}} \mathrm{O}$ by reaction (5) can take place.

Above there is discussed the thermodynamics of the processes, in the reaction zone of which present are only the elements that are constituents of the initial and end products of the reaction - calcium, oxygen, reducible and alloying metals.

From a technical point of view, it turned out to be promising to use in the processes of calciothermic reduction some auxiliary substances, the elements of which are not consumed in the reaction and are not included into the final products. The advisability of using such substances may have economic, ecological or technical reasons. Economic reasons are the consequence of using cheaper initial materials than metal calcium, simpler and cheaper ways of preparing the original charge, extracting and cleaning the final products. Ecological reasons lie in the possibility of easier and fine cleaning of flushing solutions at the final operations of calcium thermal reduction.

The most prevalent and commonly used auxiliaries in calciothermic processes are calcium hydride and calcium chloride. The thermodynamics of processes with the use of these substances is discussed below.

\subsection{Thermodynamics of calcium hydride reduction}

The application of calcium metal for reduction of thermodynamically strong oxides in industrial conditions is difficult, since it is almost impossible to make a dispersed powder from it, which is necessary to obtain a homogeneous charge mixture.

In this connection it is advisable to use brittle calcium hydride $\mathrm{CaH}_{2}$, obtained by the interaction of calcium metal with hydrogen at temperatures of $400-500{ }^{\circ} \mathrm{C}$ by exothermic reaction $(192.6 \mathrm{~kJ} / \mathrm{mol})$, as a reducing agent:

$$
\mathrm{Ca}+\mathrm{H}_{2}=\mathrm{CaH}_{2}
$$


Calcium hydride is a brittle salt-like compound of ionic type, which is easily crushed into a powder, thus allowing to obtain homogeneous mixtures with powders of metals and their oxides. At temperatures above $800{ }^{\circ} \mathrm{C}$, $\mathrm{CaH}_{2}$ is actively decomposing with formation of calcium and atomic hydrogen. The latter instantly forms the hydrogen molecule $\mathrm{H}_{2}$. Meerson G. A. and Kolchin O. P. have shown by thermodynamic calculations and experimentally that the main role in reduction of chemically strong oxides plays calcium in the liquid and partially gaseous states rather than atomic hydrogen, the reducing activity of which is significantly lower than that of calcium [33].

When analyzing the equilibrium state in a calciumhydrogen system, one should take account of not only the influence of temperature, but also a pressure, that is, to consider the phase diagram in the temperature-pressurecomposition coordinates [34-35]. Due to the complexity of constructing and perception of information on such three-coordinate diagrams, it is advisable to consider twocoordinate diagrams that are cross-sections or projections of the three-coordinate diagram.

Two-coordinate diagrams for calcium-hydrogen system are represented in Fig. 2-5.

The diagram in Fig. 2 is a projection of the maximum solubility lines of the $\mathrm{Ca}-\mathrm{H}$ three-coordinate phase diagram onto the temperature-composition plane. One cannot use this diagram to determine the equilibrium phase

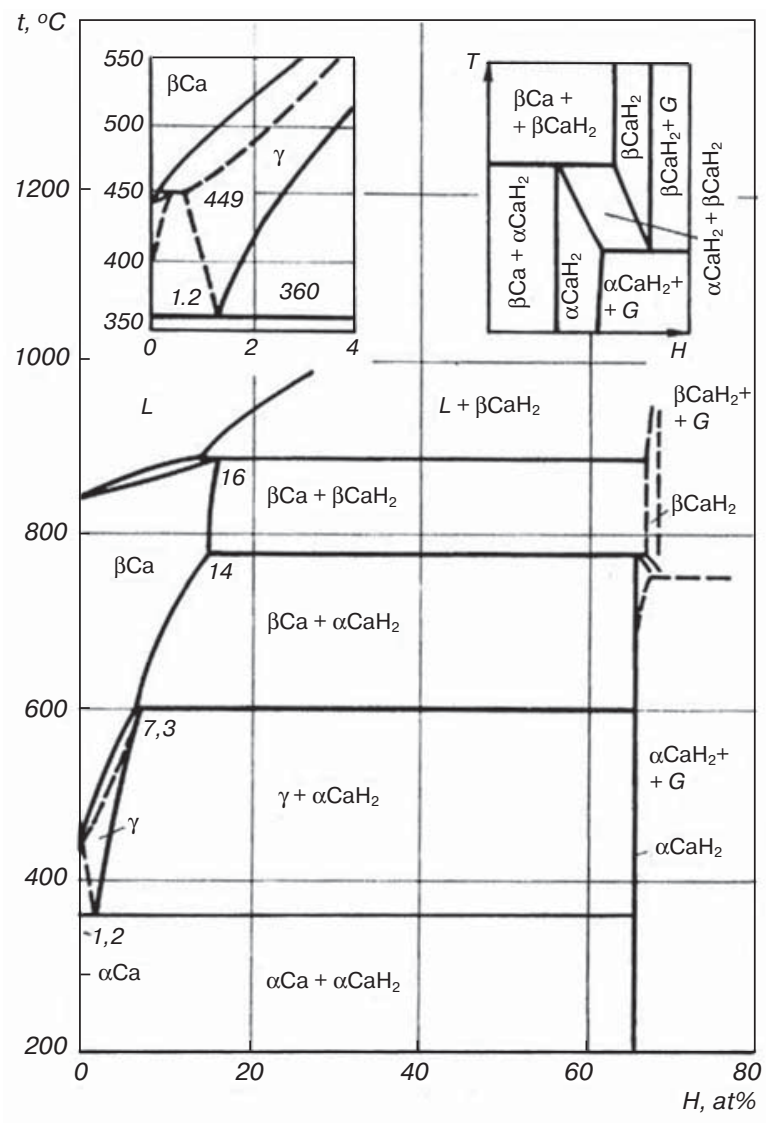

Fig. 2. Projection of the peak solubility lines of $\mathrm{Ca}-\mathrm{H}$ system onto the temperature-composition plane at different hydrogen pressure [4] composition without additional information about isotherms or isobars of hydrogen solubility.

The diagram in Fig. 3 is a projection of the three-phase invariant equilibrium lines onto the pressure-temperature plane. This diagram gives an idea of the phase transformations in $\mathrm{Ca}-\mathrm{H}$ system and allows one to build isobaric and isothermal cross-sections, but it also cannot be used to determine compositions of the equilibrium phases.

Fig. 4 demonstrates an example of an isobaric crosssection of a spatial diagram of $\mathrm{Ca}-\mathrm{H}$ system. Such diagrams serve as typical example of type II diagrams in which an intensive property (temperature, pressure) is laid off along one coordinate axis, and an extensive property (composition) is plotted on the other [36]. These diagrams make it possible to determine the equilibrium phase compositions at given values of temperature and pressure.

A type I diagram [36] in the hydrogen pressure - temperature coordinates is shown in Fig. 5. It defines the domains of existence of different phases at given values of two intensive properties (temperature and pressure). Only single-phase domains are indicated in this diagram. The equilibrium compositions of these phases can only be determined if there are isotherms or isobars of hydrogen solubility. Such isotherms are available in [34-35].

The behavior of calcium hydride when heated in argon to a temperature of $1200^{\circ} \mathrm{C}$ was studied in [37]. Fig. 6 illustrates the results of thermal analysis obtained in this work, carried out on a differential scanning calorimeter on being heated in the temperature range of $20-1200{ }^{\circ} \mathrm{C}$ at a rate of $10^{\circ} \mathrm{C} / \mathrm{min}$.

Analysis of thermograms (Fig. 6) using the dependences of hydrogen equilibrium pressure upon the temperature during $\mathrm{CaH}_{2}$ dissociation [34]:

$$
\begin{aligned}
& \lg P_{\mathrm{H}_{2}}=12.32-9610 / T\left(600-780^{\circ} \mathrm{C}\right) \\
& \lg P_{\mathrm{H}_{2}}=11.62-8890 / T\left(780-890^{\circ} \mathrm{C}\right)
\end{aligned}
$$

has demonstrated, that the process of calcium hydride dissociation begins at a temperature above $345{ }^{\circ} \mathrm{C}$, but

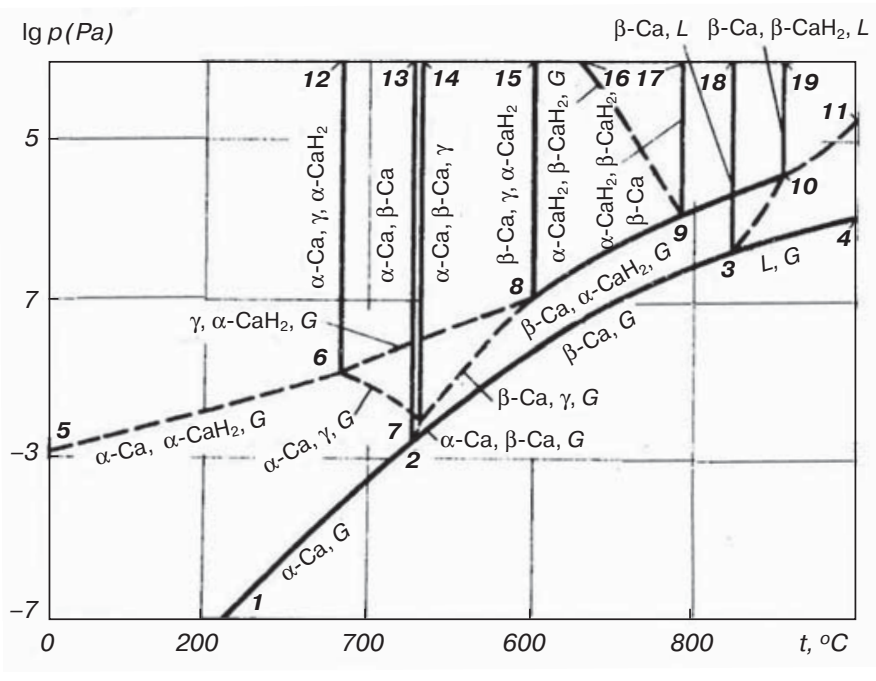

Fig. 3. P-T phase diagram of $\mathrm{Ca}-\mathrm{H}$ system [35-36] 

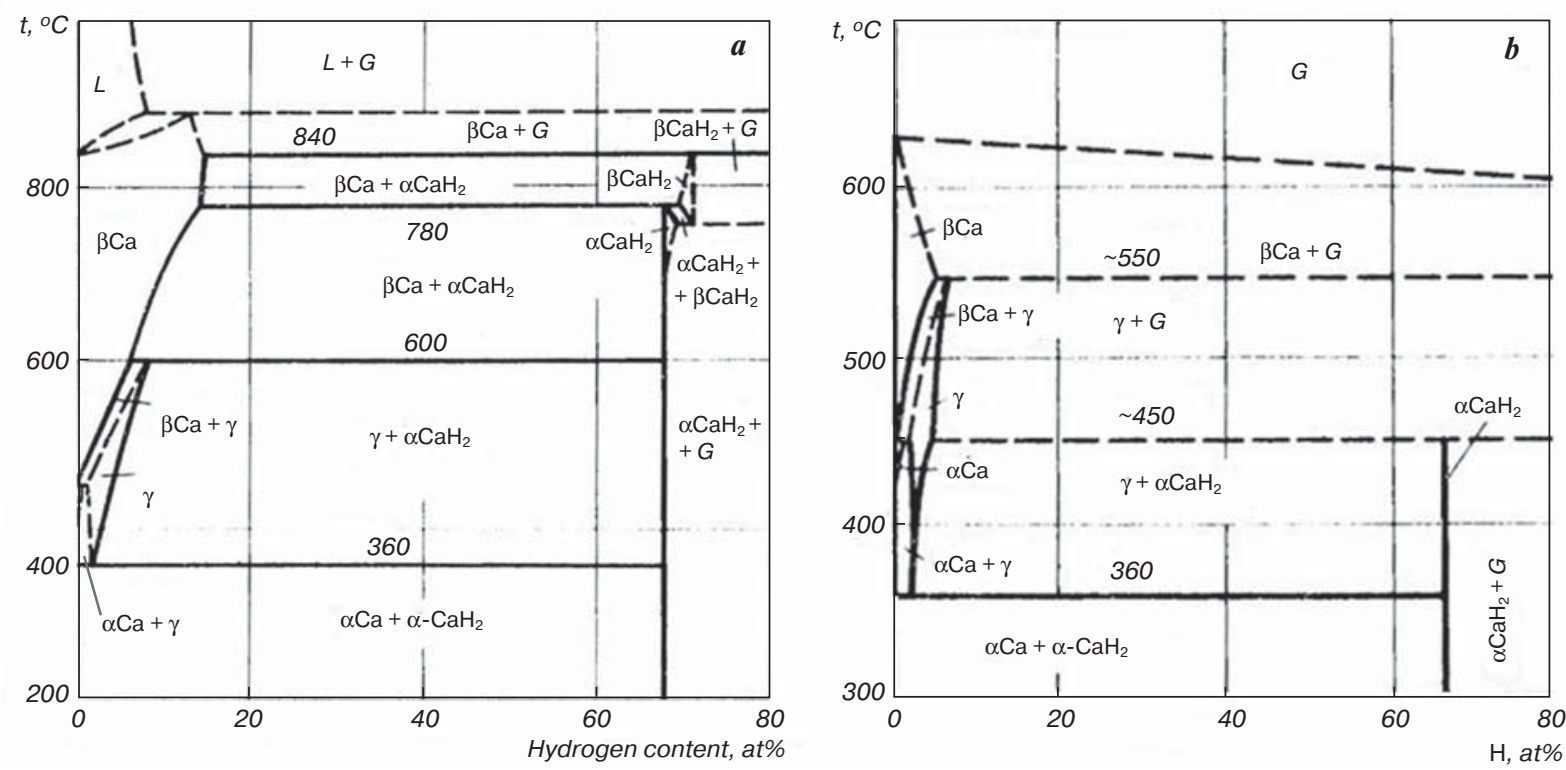

Fig. 4. Isobaric cross-sections of phase diagram of $\mathrm{Ca}-\mathrm{H}$ system at pressures of $5 \cdot 10^{3} \mathrm{~Pa}(a)$ and $1 \mathrm{~Pa}(b)$ [35]

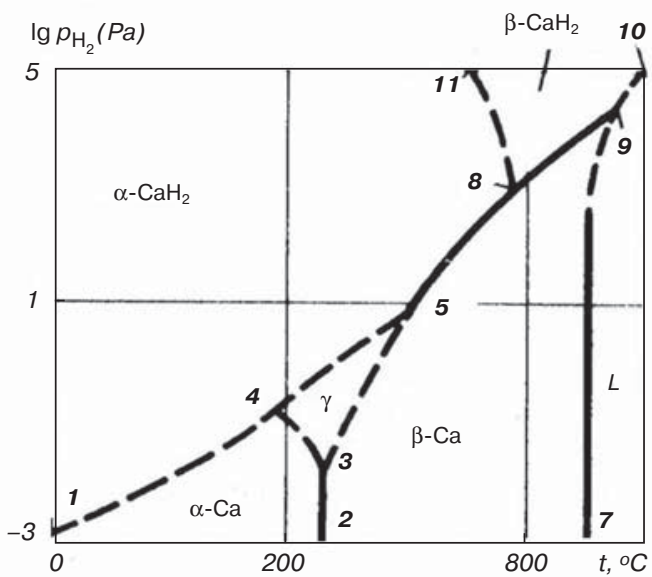

Fig. 5. $\mathrm{P}_{\mathrm{H}_{2}}$-T phase diagram of $\mathrm{Ca}-\mathrm{H}$ system [35]

active phase transformations take place at a temperature above $800{ }^{\circ} \mathrm{C}$. At first, a solid-phase polymorphic conversion of $\alpha-\mathrm{CaH}_{2} \rightarrow \beta-\mathrm{CaH}_{2}$ is performed with a maximum endothermic effect at $815-818{ }^{\circ} \mathrm{C}$; starting from the temperature of $825-827^{\circ} \mathrm{C}$, an intense dissociation of calcium hydride occurs with simultaneous calcium melting and the formation of a melt by $\beta-\mathrm{CaH}_{2} \rightarrow L+$ $+\mathrm{H}_{2} \uparrow$ reaction. The melting point of $\mathrm{Ca}$ is $840^{\circ} \mathrm{C}$, but according to [38], the presence of impurities in industrial calcium leads to a significant decrease in the melting temperature.

The processes, which occur on heating a mixture of powders of calcium hydride and metal oxide, can be traced by the example of $\mathrm{CaH}_{2}+\mathrm{TiO}_{2}$ mixtures. When such mixture is heated, the decomposition of calcium hydride takes place sequentially, which sharply increases when the melt appears near $825-850{ }^{\circ} \mathrm{C}$; at this temperature, the process of $\mathrm{TiO}_{2}$ reduction begins (Fig. 7).

When heating the mixtures of $\mathrm{CaH}_{2}$ powder with powders of two or more metal oxides, the reduction processes
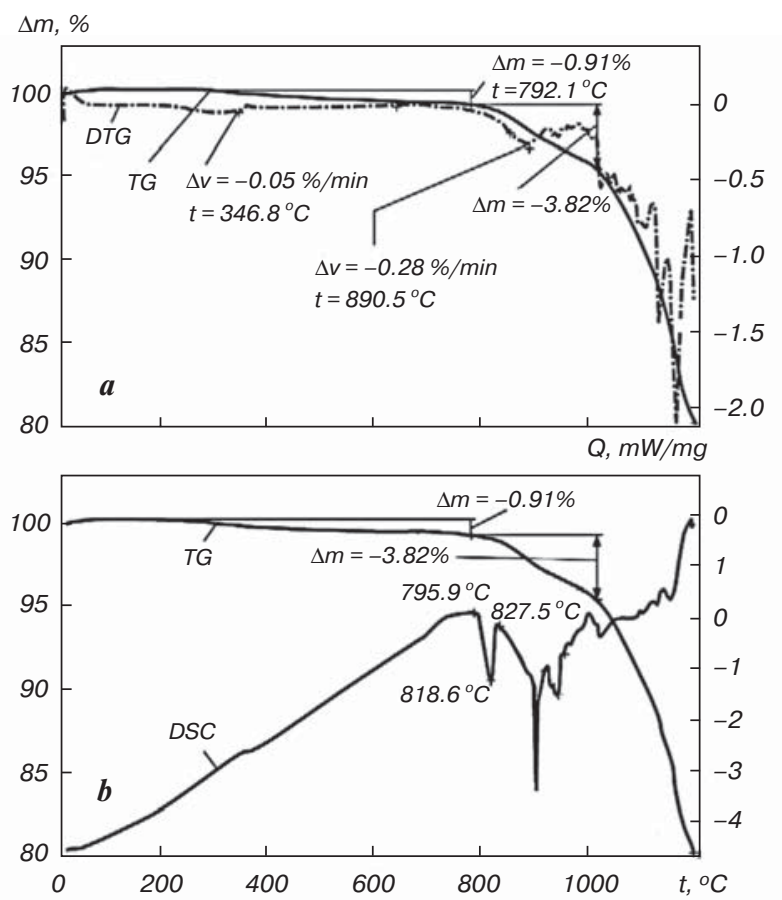

Fig. 6. Thermogravimetric curves of $\mathrm{CaH}_{2}$ when heated in argon up to $1200^{\circ} \mathrm{C}, V=10^{\circ} / \mathrm{min}$ :

$a$ - temperature dependences of mass change (TG thermogravimetry) and mass change rate (DTG - differential thermogravimetry); $b$ - dependences of mass change TG and calorific effects (DSC - differential scanning calorimetry) on temperatur

of particles of different metals happen simultaneously orsequentially with the formation of powders of alloys or intermetallic compounds at the final stage according to the following scheme:

$$
\begin{aligned}
& M e^{\mathrm{I}} \mathrm{O}+M e^{\mathrm{II}} \mathrm{O}\left(M e^{\mathrm{II}}\right)+ \\
& +\mathrm{CaH}_{2} \leftrightarrow\left(\mathrm{Me}^{\mathrm{I}} \mathrm{Me}^{\mathrm{II}}\right)+\mathrm{CaO}+\mathrm{H}_{2} \uparrow .
\end{aligned}
$$




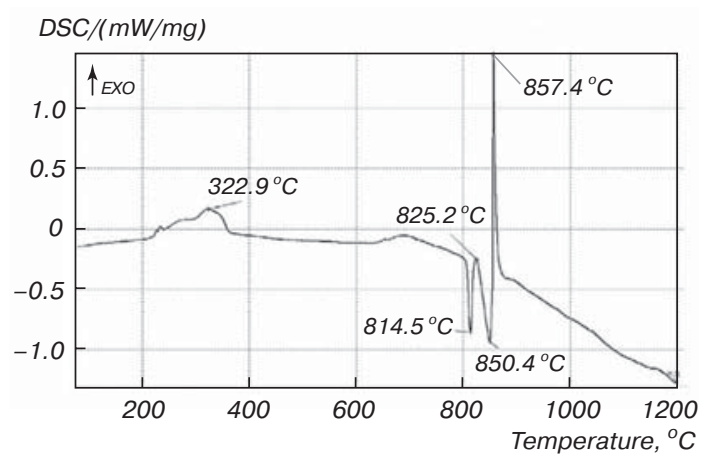

Fig. 7. Thermogram for heating $\mathrm{a} \mathrm{CaH}_{2}+\mathrm{TiO}_{2}$ mixture within the range of $20-1200{ }^{\circ} \mathrm{C}$

The reducing agent in this process is still calcium metal, which is in a liquid state. The reduction stage in complex systems usually takes place at temperatures around $900{ }^{\circ} \mathrm{C}$, and alloy formation becomes noticeable at these temperatures. An examination of the processes that occur in this case by the example of the formation of intermetallic compounds $\mathrm{TiNi}, \mathrm{TiFe}, \mathrm{TiAl}, \mathrm{NiAl}, \mathrm{Ni}_{5} \mathrm{La}$, $\mathrm{SmCo}_{5}, \mathrm{ZrAl}$ and others will be discussed below.

\subsection{Thermodynamics of calcium chloride reduction of metal oxides}

Recently, varieties of calciothermic reduction of metal oxides with the use of calcium chloride $\mathrm{CaCl}_{2}$ as an auxiliary substance have become widely used [6, 7, 9, 12, 21, 39-43]. This group includes such methods as FFC, OS, EMR, ESR, ISIB, EMRI MSE, and RPR.

Due to widespread use of calcium chloride in calcium thermal reduction, it is interesting to consider in more detail the properties of this compound and the phase equilibriums in $\mathrm{Ca}-\mathrm{CaO}-\mathrm{CaCl}_{2}$ system.

Calcium chloride $\mathrm{CaCl}_{2}$ is a compound with an ionic type of chemical bond. In its normal state, it is a hygroscopic powder with a density of $2.15 \mathrm{~g} / \mathrm{cm}^{3}$, a melting point of $772{ }^{\circ} \mathrm{C}$ and a boiling point of $1600{ }^{\circ} \mathrm{C}$.

Up to $20 \mathrm{~mol} \% \mathrm{CaO}$ and about $4 \mathrm{~mol} \% \mathrm{Ca}$ can be dissolved in molten $\mathrm{CaCl}_{2}$ [9-10, 41, 43]. Segment of the isothermal cross-section of a ternary phase diagram of $\mathrm{CaCl}_{2}-\mathrm{CaO}-\mathrm{Ca}$ system at a temperature of $927^{\circ} \mathrm{C}$ is shown in Fig. 8. Calcium activity in its saturated solution

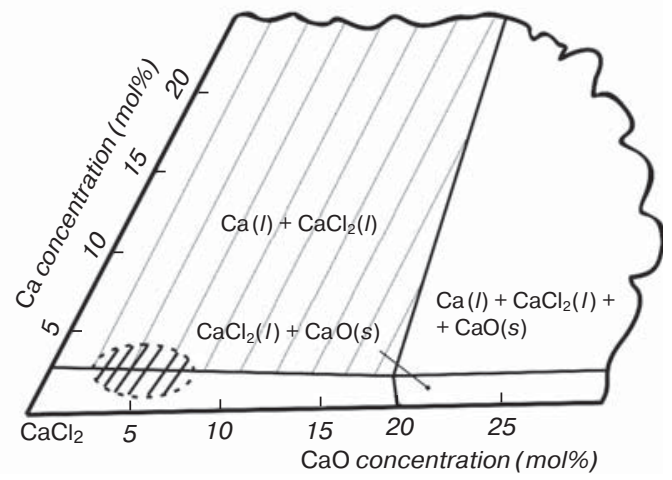

Fig. 8. Part of an isothermic cross-section of ternary phase diagram of $\mathrm{CaCl}_{2}-\mathrm{CaO}-\mathrm{Ca}$ system at a temperature of $927^{\circ} \mathrm{C}$ in $\mathrm{CaCl}_{2}$ is equal to 1 . In accordance with this, the reducing ability of such a solution is the same as that of pure calcium. The activity of calcium and its reducing capabilities to decrease residual oxygen in the solid solution after the reduction of metal oxides decreases, as the calcium concentration in $\mathrm{CaCl}_{2}$ solution relative to the saturated one lessens.

As it is shown in [21], the oxygen content in a Ti-based solid solution in the equilibrium state of the system:

$$
\mathrm{O} \text { (in } \mathrm{Ti})+\mathrm{Ca}\left(\text { in } \mathrm{CaCl}_{2}\right) \leftrightarrow \mathrm{CaO}\left(\text { in } \mathrm{CaCl}_{2}\right. \text { ) }
$$

is defined by equation:

$$
\ln ([\mathrm{O}])=\ln (r)-7020 / T+2.49,
$$

where [O] is concentration of $\mathrm{O}$, at $\% ; r=a_{\mathrm{CaO}} / a_{\mathrm{Ca}}$; $T$ is temperature, $\mathrm{K}$.

Temperature dependences of the oxygen content in a solid titanium solution calculated by equation (12) for different values of $r$ are shown in Fig. 9. The hatched graph segment indicates an area of experimentally obtained values of the oxygen amount in titanium, which are presented in different papers [4, 21, 41, 44].

As appears from Fig. 9 and equations (11) and (12), the minimum oxygen content in the final product may be achieved if the reduction process is performed at $a_{\mathrm{Ca}}=1$ and $a_{\mathrm{CaO}}<1$, to which the hatched area of the diagram in Fig. 8 corresponds.

In practice, it is difficult to keep optimal reduction conditions during entire process, since $\mathrm{CaO}$ is continuously formed during the reaction and $\mathrm{Ca}$ content decreases, the $r$ value rises and the oxygen content in the resulting titanium-based solid solution increases.

The densities of liquid $\mathrm{Ca}, \mathrm{CaCl}_{2}$ and solid $\mathrm{TiO}_{2}$ particles at $900{ }^{\circ} \mathrm{C}$ are $1.357,2.01$ and $4.23 \mathrm{~g} / \mathrm{cm}^{3}$, respectively.

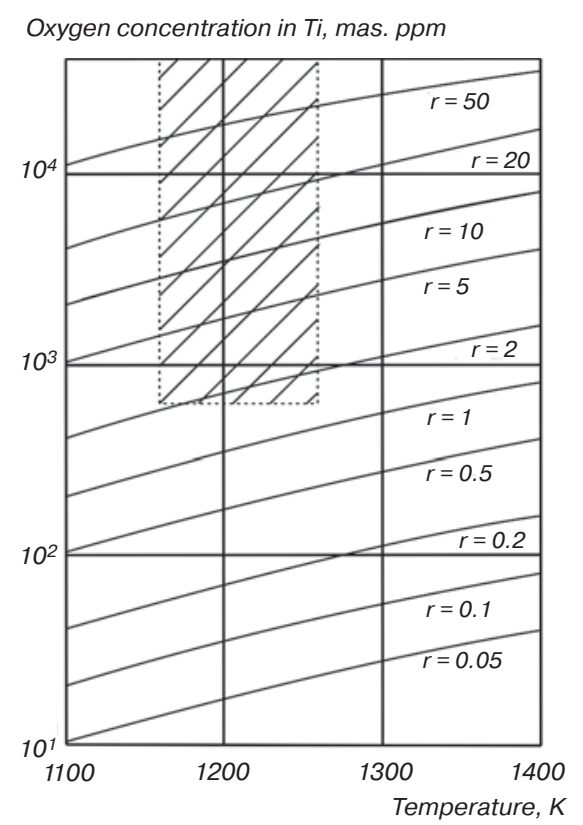

Fig. 9. Equilibrium concentration of oxygen in titanium. The ratio of $\mathrm{CaO}$ and $\mathrm{Ca}$ activities is denoted by an ' $r$ ' symbol [21] 
Such a large difference in density leads to the fact that the molten Ca does not contact directly with $\mathrm{TiO}_{2}$ in real production devices. Nevertheless, $\mathrm{Ca}$ is fairly well dissoluble in $\mathrm{CaCl}_{2}\left(3.9 \mathrm{~mol} \%\right.$ at $\left.900{ }^{\circ} \mathrm{C}\right)$ with the resulting contact of $\mathrm{Ca}$ with $\mathrm{TiO}_{2}$ particles.

Generally, as appears from the given thermodynamic estimates, the closer the system is to equilibrium, the less final metal contains oxygen, but the more expensive the product will be, since achieving an equilibrium state requires a long time and decreases productivity. Besides, the inevitable oxidation of the powder occurs and the amount of oxygen in it increases because of washing, crushing, drying. That is why the experimentally obtained values of the oxygen content in titanium, which are shown in Fig. 9, exceed the ones calculated for equilibrium conditions.

It is interesting nevertheless to note that as follows from Fig. 8 and 9 and equations (11) and (12), the reduction in the presence of $\mathrm{CaCl}_{2}$ melt has the principal possibility of a deeper purification of metals from oxygen impurity than calcium reduction even at $a_{\mathrm{Ca}}=1$.

To use this feature, it is necessary to perform reduction in a $\mathrm{CaCl}_{2}$ melt under conditions with $a_{\mathrm{CaO}}<<1$.

\section{Mechanism and kinetics of reduction processes}

The process of reducing solid metal oxide particles with calcium melt consists in the disappearance of solid particles of original oxide and formation of solid metal particles and calcium oxide. The system transition from initial non-equilibrium state to the final equilibrium one can be carried out using three main mechanisms.

The first mechanism consists in the adsorption of calcium atoms from the melt to the surface of original oxide particles, formation of calcium oxide layers on the surface of particles, following diffusion of oxygen atoms into these layers and formation of solid metal particles in place of the central parts of original oxide particles. This mechanism is carefully examined in [21] using the example of $\mathrm{TiO}_{2}$ particle reduction.

The second mechanism, known as 'fragmentation' and thoroughly studied in powder metallurgy by the example of liquid phase sintering [45], involves rapid diffusion of calcium atoms from the surface of original oxide particles towards the center along the boundaries of oxide grains, the formation and growth of $\mathrm{CaO}$ layers on each of oxide grains, and resulting initial oxide particle splitting into the number of particles corresponding to the number of grains that made it up.

The third mechanism is a sort of recrystallization through the liquid phase, also known in the theory of sintering [45-46]. It implies that original oxide particles are dissolved in the calcium melt, the nuclei are formed and metal particles grow from them in the calcium melt.

The predominance of any of these mechanisms is determined by many factors. The main ones are the average size of original oxide particles and their size distribution, structure and state of the surface of oxide particles, chemical composition of the initial mixture, the reduction temperature, and technological features of the process (gas composition and pressure, mixing, force field impacts, etc.).

Each of these factors initiates a specific reduction mechanism. In particular, large monocrystalline oxide particles tend to the reduction by the first mechanism, polycrystalline particles by the second, and fine and nanocrystalline particles - through the third one.

In practice, especially if having regard to the fact that all commercial-grade powders are characterized by the particle size distribution, one can expect the demonstration of all three mechanisms in different proportion in all the reduction cases.

Mechanisms of high-temperature electrolytic calciothermic reduction are not considered in the review, since they call for separate discussion. It is only possible to point out the works [6-10], in which individual features of the electrolytic reduction mechanisms are implemented jointly or parallel with the above-mentioned ones.

The mechanism of reduction of oxide particles by calcium vapor in the absence of a liquid phase in the form of pure calcium or its solution in $\mathrm{CaCl}_{2}$ is similar to the first option described above.

The rate of calciothermic reduction is influenced by: temperature; size, composition and structure of the original oxide particles; composition of the initial charge (the ratio of metal oxide and calcium), calcium state in the form of vapor, melt, solution in calcium chloride or another solvents; processing factors (features of the reactor design, a possibility of mixing during reduction, a possibility of affecting by the force fields, such as ultrasound), composition and pressure of gases in the reactor atmosphere.

The deciding factor affecting the reduction rate is temperature. Most of the processes that define all three reduction mechanisms described above are diffusive. The rate of diffusion depends exponentially on temperature, hence the reduction reaction rate, as a whole, also depends on temperature exponentially.

It has been experimentally established that the temperature of calciothermic reduction of all metal oxides lies in the range of $800-1100^{\circ} \mathrm{C}$. Within these limits, the process rate increases multiply. But in practice, when choosing the reduction temperature, one have to be guided not only by the process rate and, accordingly, on its efficiency, but also by the capacity for work of the reactor metal structures, as well as by an increase in the reduced metals of the impurities dissolved in them as well as oxygen in some cases. The latter option relates, in particular, to titanium, which has a transition temperature $(\alpha-\beta)$ of $885^{\circ} \mathrm{C}$, and contains more oxygen in the $\beta$-solid solution than in the $\alpha$-solid one.

\section{Process flowsheets and equipment}

As indicated earlier, many variants of calciothermic reduction are currently being developed. Among manufacturing operation of these methods, it is possible to pick 


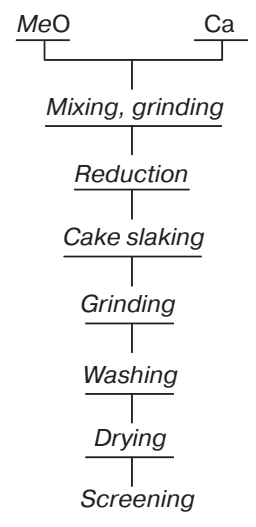

Fig.10. Basic process flowsheet of calciothermic reduction out both main operations, which are present in almost all methods, and the individual ones.

Processing and preparation of raw materials, preparation of charge, reduction, hydrometallurgical treatment of reduction products: slaking of sintered reaction products (cake), cake grinding, washing, drying and screening of powder may be attributed as main operations.

The basic flowsheet of calciothermic reduction is shown in Fig. 10.

Some oxides, especially the hygroscopic ones $\left(\mathrm{TiO}_{2}, \mathrm{Cr}_{2} \mathrm{O}_{3}\right)$, are calcined at $800-900^{\circ} \mathrm{C}$ before mixing and grinding. Mixing and grinding are most often carried out in ball mills; the ball material and sometimes the lining of the drum walls are chosen taking into account the minimization of resulting contamination of the source materials.

Reduction is usually implemented at temperatures of $800-1200{ }^{\circ} \mathrm{C}$ in reactors that have peculiar features for each reduction method.

Cake slaking, grinding, washing, drying and screening are carried out using standard metallurgical equipment in accordance with the process flowsheet (Fig. 11) [4].

When slaking the crushed cake, calcium oxide and excess calcium react with water to form calcium hydroxide $\mathrm{Ca}(\mathrm{OH})_{2}$ and a small amount of hydrogen from the interaction of $\mathrm{Ca}$ with $\mathrm{H}_{2} \mathrm{O}$. These reactions are accompanied by heat release. To avoid oxidation of the reduced metal, the slaking temperature is maintained no higher than $60^{\circ} \mathrm{C}$, which is regulated by the water supply.

After slaking, the cake is subjected to wet grinding in ball mills. The resulting pulp is treated with hydrochloric acid. As a result of the interaction of calcium hydroxide with acid, a well-soluble in water calcium chloride is formed:

$$
\mathrm{Ca}(\mathrm{OH})_{2}+2 \mathrm{HCl}=\mathrm{CaCl}_{2}+2 \mathrm{H}_{2} \mathrm{O} \text {. }
$$

The treatment is carried out on constant stirring and water supply up to $\mathrm{pH} 5-6$. The treatment temperature

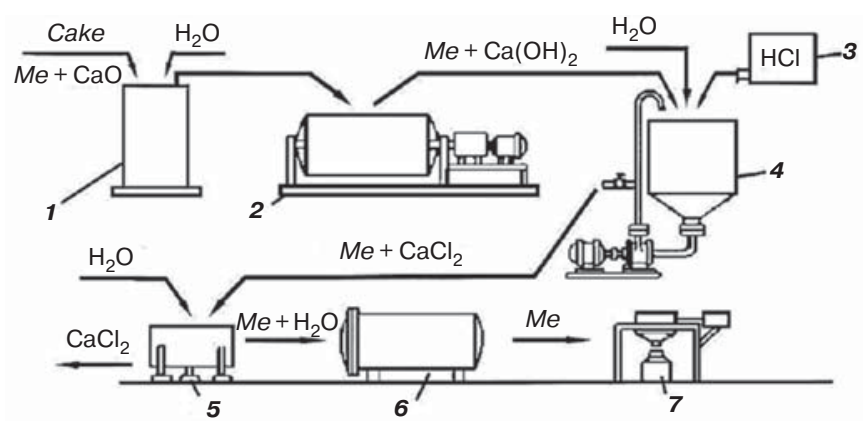

Fig. 11. Process flow diagram of hydrometallurgical processing of a cake: 1 - tank for slaking, 2 - evaporator, 3 - acid gauging tank, $4-$ tank for leaching, 5 - centrifuge, 6 - vacuum drying oven, $7-$ screen machine should not exceed $40{ }^{\circ} \mathrm{C}$. After acid treatment, the powder is washed from calcium chloride with water and dehydrated by centrifugation, then subjected to vacuum drying and screening.

The process flowsheet (Fig. 10) is valid for the simplest cases of applying the Kroll process for the molten calcium reduction of oxide of one metal, for example, titanium dioxide. Process flowsheets become more complicated for more intricate cases, for example: when using mixtures of oxides and metals as initial substances to produce powders of metal alloys or intermetallic compounds; when introducing auxiliary substances (calcium hydride, calcium chloride, etc.) into the reaction zone; on combining the calcium reduction process with electrolysis, etc. An example of such a scheme for calcium hydride process is shown in Fig. 12.

Instrumentation of numerous variants of engineering processes of calciothermic reduction is mainly provided by standard equipment used in metallurgical and chemical industries. The exception is the apparatus of the main, principal operation of calcium thermal

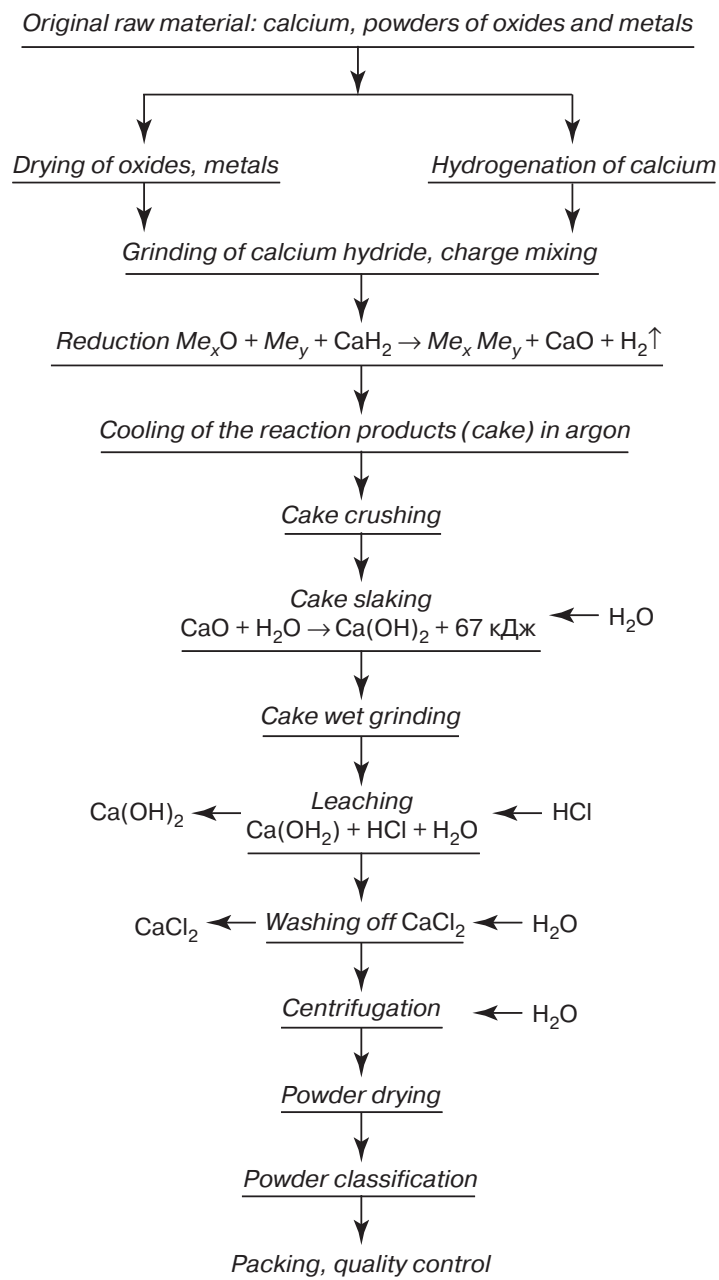

Fig. 12. Process flowsheet of manufacturing powders of metals and alloys by calcium hydride method 


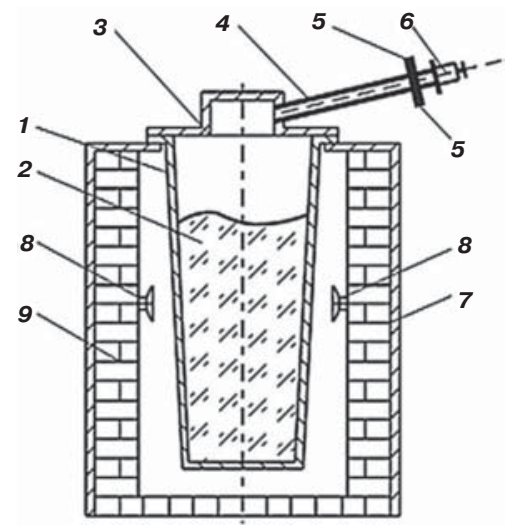

Fig. 13. Scheme of a gas-heated shaft furnace [4]:

1 - container; 2 - charge; 3 - retort cover; 4 - central branch pipe; 5 - side branch pipes; 6 - plug; 7 - furnace; 8 - gas burners; 9 - furnace refractory masonry

reduction - a high-temperature reduction of oxides. These operations are performed in high-temperature reactors, the design features of which embody the main distinctions between the reduction methods.

The main requirements for the materials of these reactors are high hot strength and corrosion resistance, and that for the constructions are the presence of a heating device, convenience of loading the initial and unloading the final reaction products, tightness and ability to work in a gas medium atmosphere of a given composition. For industrial reactors it is desirable to predict the possibility of continuous process.

Research laboratory reactors differ in the use of various design and corrosion-resistant high-temperature steels, alloys and ceramics. In some reactors, the reactor volume is divided into two parts. At the bottom, there is a bath for melting calcium or calcium in calcium chloride; at the top part, separated from the bottom one by a lattice, there is placed the metal oxide being reduced in the form of the pieces or porous briquettes compressed from powders. In this case, the melt does not directly interact with the solid oxide, and the reduction takes place in calcium vapors $[9,19,40,47-49]$.

Fig. 13 shows the scheme of an industrial-scale plant for producing calciothermic powders of metals and alloys [4].

A heat-resistant chromium-nickel $(0.2 \mathrm{C}, 22.0-25.0 \mathrm{Cr}$, 17.0-20.0 Ni, 1.0 Si, 2.0 Mn, wt.\%) steel container of diameter $620-720 \mathrm{~mm}$ is placed into the furnace lined with refractory masonry. The furnace is heated by gas burners that provide an operating temperature up to $1200{ }^{\circ} \mathrm{C}$. Container with the charge is installed into a furnace preheated up to $700-800{ }^{\circ} \mathrm{C}$ using a jib. The furnace temperature is being increased for $4-8$ hours to $1200 \pm 30^{\circ} \mathrm{C}$, next is the holding for $8-20$ hours. Reduction is carried out in argon. After cooling, the container with the reaction products is sent to the hydrometallurgical processing area. The output of such a process in one cycle reaches $250 \mathrm{~kg}$ of the finished powder, depending on unit weight of the material.

\section{Composition, structure and properties of powders 4.1. Metals and alloys \\ 4.1.1. Titanium and its alloys}

The process of obtaining titanium powder is historically one of the best-understood in calcium thermal reduction. The purpose of many studies on this topic was not only to obtain a valuable commercial product (titanium powder), but also to research into the regularities of a calciothermic process as a whole. The advantages and disadvantages of various variants of this method have been studied by the example of titanium dioxide reduction.

Metallothermic production of titanium sponge and powder originated in works by W. J. Kroll [1-2]. The methods and apparatus of these works were later used as the basis for calciothermic reduction of titanium dioxide as well. Rapid development of these works took place at the end of the last century and the beginning of the present one.

Calciothermic powders of titanium have been obtained at once by the Kroll process [15], calcium hydride method [4-5, 50], calcium reduction if there is $\mathrm{CaCl}_{2}[21]$, calcium vapor reduction [12, 42], combined calcium and electrochemical reduction methods $[6,9-10,51]$. Thermodynamics, mechanisms, process flowsheets and apparatuses of these processes are described in the previous sections, and properties of the obtained powders are listed in Table 3.

Particular attention in studies of calciothermic reduction of titanium dioxide has been given to identifying the potential of the deepest possible titanium refinement from oxygen impurities in its solid solution. Thermodynamic calculations have shown that it is possible to remove oxygen from titanium up to infinitesimals [21]. Moreover, the depth of cleaning from oxygen is determined not only by the calcium affinity to oxygen at $a_{\mathrm{Ca}}=1$, but also by the minimum possible values of activities of oxidation products, i.e. by the ratio $r=a_{\mathrm{CaO}} / a_{\mathrm{Ca}}$ [21]. The possibility of reducing the magnitude of $a_{\mathrm{CaO}}$ and therefore that of $r$ to very small values occurs when using a melt in which not only $a_{\mathrm{Ca}}=1$, but also $a_{\mathrm{CaO}}<<1$, as a deoxidizing medium. Such a medium, in particular, is the $\mathrm{CaCl}_{2}$ melt. In practice, as shown in [21], when comparing thermodynamic calculations with experimental values of various works, the degree of purification from oxygen is 10-100 times worse (Fig. 9). This is explained by the fact that under the conditions close to equilibrium, the reduction process progresses infinitely slow and takes place at values of $r=0.2-0.4$, which corresponds to the oxygen content in a solid titanium solution of $\mathrm{C}_{\mathrm{O}}=10^{3}-10^{5} \mathrm{ppm}$.

\subsubsection{Hafnium}

Hafnium powder was obtained in [56] by calcium reduction from $\mathrm{HfO}_{2}$ powder by the Kroll process in a steel hermetic retort in an argon atmosphere. Chemical composition and properties of the powder are given in Table 3. 
Table 3.

Properties of calciothermic powders of metals and alloys

\begin{tabular}{|c|c|c|c|c|c|c|c|c|c|c|c|c|}
\hline \multirow{3}{*}{ No. } & \multirow{3}{*}{ Original charge } & \multicolumn{7}{|c|}{ Chemical composition of the finished powders, wt $\%$} & \multicolumn{2}{|c|}{ Properties } & \multirow{3}{*}{ Method of making } & \multirow{3}{*}{ Source } \\
\hline & & \multirow{2}{*}{$\begin{array}{l}\text { Base } \\
\text { metal }\end{array}$} & \multirow{2}{*}{$\begin{array}{l}\text { Alloying } \\
\text { element }\end{array}$} & \multicolumn{5}{|c|}{ Impurities } & \multirow{2}{*}{$d_{\mathrm{av}}, \mu \mathrm{m}$} & \multirow{2}{*}{ Others } & & \\
\hline & & & & $\overline{0}$ & $\bar{C}$ & $\overline{\mathrm{H}}$ & $\overline{\mathrm{Ca}}$ & The rest & & & & \\
\hline 1 & $\begin{array}{l}\mathrm{TiO}_{2} \text { powder, } \\
\mathrm{Ca} \text { granules }\end{array}$ & $\mathrm{Ti}$ & - & $0.13-0.18$ & - & - & - & - & $2-6$ & - & Kroll process & [15] \\
\hline 2 & $\begin{array}{l}\mathrm{TiO}_{2} \text { powders, } \mathrm{Ca} \text {, } \\
\mathrm{CaH}_{2} \text { granules }\end{array}$ & $\mathrm{Ti}$ & - & $0.2-0.3$ & 0.05 & 0.35 & 0.08 & $\begin{array}{c}\mathrm{Cl}-0.04 \\
\mathrm{Si}-0.10 \\
\mathrm{~N}-0.08 \\
\sum(\mathrm{Fe}+\mathrm{Ni})=0.4\end{array}$ & $40-60$ & $\begin{array}{l}\text { Bulk density } \\
1-1.5 \mathrm{~g} / \mathrm{cm}^{3} \\
\text { doesn't flow }\end{array}$ & $\begin{array}{l}\text { Calcium hydride } \\
\text { method }\end{array}$ & [4] \\
\hline 3 & $\begin{array}{l}\mathrm{TiO}_{2} \text { powder } \\
\text { (rutile, anatase), } \\
\text { Ca granules, } \mathrm{CaCl}_{2} \\
\text { powder, } \\
\mathrm{CaClO}_{4} \text { powder }\end{array}$ & $\mathrm{Ti}$ & - & $0.10-0.15$ & - & - & - & - & $10-20$ & - & $\begin{array}{l}\text { Method with the } \\
\text { use of } \mathrm{CaCl}_{2} \text { melt }\end{array}$ & $\begin{array}{l}{[21,} \\
52]\end{array}$ \\
\hline 4 & $\begin{array}{l}\mathrm{TiO}_{2} \text { powder, } \mathrm{CaCl}_{2} \\
\text { powder, Ca granu- } \\
\text { les, coarse } \mathrm{Ti}\end{array}$ & $\mathrm{Ti}$ & - & 0.09 & - & - & 0.17 & Si-0.28 & $8-15$ & - & $\begin{array}{l}\text { Ca vapor } \\
\text { reduction }\end{array}$ & $\begin{array}{l}{[53-} \\
54]\end{array}$ \\
\hline 5 & $\begin{array}{l}\mathrm{TiO}_{2} \text { powder, } \mathrm{CaCl}_{2} \\
\text { powder, } \\
\text { Ca granules }\end{array}$ & $\mathrm{Ti}$ & - & 0.08 & - & - & - & - & 5 & - & $\begin{array}{l}\text { Method of com- } \\
\text { bined calcium and } \\
\text { electrochemical } \\
\text { reduction }\end{array}$ & $\begin{array}{c}{[6,9-} \\
10]\end{array}$ \\
\hline 6 & $\begin{array}{l}\mathrm{TiO}_{2}, \mathrm{Nb}_{2} \mathrm{O}_{5}, \mathrm{Ta}_{2} \mathrm{O}_{5} \\
\text { powders, } \\
\text { lump } \mathrm{CaH}_{2}\end{array}$ & $\mathrm{Ti}$ & $\begin{array}{l}\mathrm{Nb}-30.1 \\
\mathrm{Ta}-17.4\end{array}$ & 0.12 & 0.081 & - & 0.43 & $\begin{array}{c}\mathrm{Ni}-0.3 \\
\mathrm{Fe}-0.085 \\
\mathrm{~N}-0.12 \\
\mathrm{~S}-0.0014\end{array}$ & 28.8 & $\begin{array}{l}\text { Bulk density } \\
1.5 \mathrm{~g} / \mathrm{cm}^{3} ; \\
\text { doesn't flow }\end{array}$ & $\begin{array}{l}\text { Calcium hydride } \\
\text { method }\end{array}$ & [55] \\
\hline 7 & $\begin{array}{l}\mathrm{TiO}_{2}, \mathrm{Nb}_{2} \mathrm{O}_{5}, \mathrm{ZrO}_{2} \\
\mathrm{CaH}_{2} \text { powders }\end{array}$ & $\mathrm{Ti}$ & $\begin{array}{c}\mathrm{Nb}-33.2 \\
\mathrm{Zr}-8.6\end{array}$ & 0.081 & - & - & 0.40 & $\begin{array}{c}\mathrm{Ni}-0.2 \\
\mathrm{Fe}-0.070 \\
\mathrm{~N}-0.072 \\
\mathrm{~S}-0.001\end{array}$ & 29.9 & $\begin{array}{l}\text { Bulk density } \\
1.2 \mathrm{~g} / \mathrm{cm}^{3} ; \\
\text { doesn't flow }\end{array}$ & $\begin{array}{l}\text { Calcium hydride } \\
\text { method }\end{array}$ & [55] \\
\hline 8 & $\begin{array}{l}\mathrm{V}_{2} \mathrm{O}_{3} \\
\mathrm{CaH}_{2} \\
\text { powders }\end{array}$ & v & - & 0.25 & 0.07 & - & 0.07 & $\begin{array}{l}\mathrm{N}-0.05 \\
\mathrm{Fe}-0.15 \\
\mathrm{Ni}-0.1 \\
\mathrm{Si}-0.1\end{array}$ & $<100$ & $\begin{array}{l}\text { Bulk density } \\
1.1-1.5 \mathrm{~g} / \mathrm{cm}^{3}\end{array}$ & $\begin{array}{l}\text { Calcium hydride } \\
\text { method }\end{array}$ & {$[4]$} \\
\hline 9 & $\begin{array}{l}\mathrm{HfO}_{2} \text { powder, } \mathrm{Ca} \\
\text { granules }\end{array}$ & $\mathrm{Hf}$ & - & 0.69 & - & - & 0.07 & $\begin{array}{c}\mathrm{Zr}-3.4 \\
\mathrm{Ti}-0.10 \\
\mathrm{Fe}-0.10\end{array}$ & - & - & Kroll process & [56] \\
\hline 10 & $\begin{array}{l}\mathrm{Nb}_{2} \mathrm{O}_{5} \text { powder, } \\
\mathrm{CaH}_{2}\end{array}$ & $\mathrm{Nb}$ & - & 0.52 & 0.012 & 1.0 & - & $\begin{array}{c}\text { Al-0.1 } \\
\text { Fe-0.025 } \\
\text { Si-0.020 } \\
\text { V-0.060 }\end{array}$ & - & - & $\begin{array}{l}\text { Calcium hydride } \\
\text { method }\end{array}$ & [23] \\
\hline 11 & $\begin{array}{l}\mathrm{Nb}_{2} \mathrm{O}_{5} \text { powder, } \mathrm{Ca} \\
\text { granules, } \mathrm{CaCl}_{2} \\
\text { powder }\end{array}$ & $\mathrm{Nb}$ & - & $0.6-0.8$ & - & - & $0.06-0.15$ & $\mathrm{Na}-0.056$ & 1 & $\begin{array}{c}S_{s p}= \\
=1.4-3.4 \mathrm{~m}^{2} / \mathrm{g}\end{array}$ & $\begin{array}{l}\text { Ca reduction } \\
\text { in a } \mathrm{CaCl}_{2} \text { melt }\end{array}$ & $\begin{array}{c}{[57-} \\
58]\end{array}$ \\
\hline 12 & $\begin{array}{l}\mathrm{Ta}_{2} \mathrm{O}_{5} \text { powder, } \\
\text { Ca granules }\end{array}$ & $\mathrm{Ta}$ & - & 0.15 & 0.28 & - & 0.08 & $\begin{array}{l}\mathrm{Fe}-0.05 \\
\mathrm{Mg}-0.08 \\
\mathrm{Nb}-0.11 \\
\mathrm{Si}-0.05\end{array}$ & - & - & Kroll process & [47] \\
\hline 13 & $\begin{array}{l}\mathrm{Ta}_{2} \mathrm{O}_{5} \text { powder, } \mathrm{Ca} \\
\text { granules, } \mathrm{CaCl}_{2} \\
\text { powder }\end{array}$ & $\mathrm{Ta}$ & - & $0.5-0.7$ & 0.075 & 0.22 & $0.01-0.06$ & $N-0.51-0.65$ & $1-5$ & $\begin{array}{c}S_{s p}= \\
=1.0-1.6 \mathrm{~m}^{2} / \mathrm{g}\end{array}$ & $\begin{array}{l}\text { Kroll process; } \\
\text { Ca reduction } \\
\text { in } \mathrm{a} \mathrm{CaCl}_{2} \text { melt }\end{array}$ & $\begin{array}{c}{[58-} \\
59]\end{array}$ \\
\hline 14 & $\begin{array}{l}\mathrm{Cr}_{2} \mathrm{O}_{3} \text { powder, lump } \\
\mathrm{CaH}_{2}\end{array}$ & $\mathrm{Cr}$ & - & - & 0.07 & - & - & $\begin{array}{c}\text { Ni-0.1 } \\
\text { Si-0.1 } \\
\text { Fe-0.2 } \\
\text { N-0.009 }\end{array}$ & $100-150$ & $\begin{array}{c}\text { Bulk density } \\
2.0-2.5 \mathrm{~g} / \mathrm{cm}^{3} \\
\text { doesn't flow }\end{array}$ & $\begin{array}{l}\text { Calcium hydride } \\
\text { method }\end{array}$ & [4] \\
\hline 15 & $\begin{array}{l}\mathrm{YF}_{3} \text { powder, } \\
\text { Ca granules }\end{array}$ & Y & - & 0.8 & - & - & - & $\mathrm{N}-0.04$ & - & - & Kroll process & [60] \\
\hline 16 & $\begin{array}{l}\text { Powders of REM } \\
\text { oxides, Ca granules }\end{array}$ & $\begin{array}{l}\mathrm{Ce} \\
\mathrm{Sm} \\
\mathrm{Y} \\
\mathrm{Dy} \\
\mathrm{Gd}\end{array}$ & - & $1.0-0.5$ & - & - & - & - & - & - & $\begin{array}{l}\text { Kroll process; } \\
\text { Ca reduction } \\
\text { in } \mathrm{a} \mathrm{Call}_{2} \text { melt }\end{array}$ & $\begin{array}{l}{[61-} \\
65]\end{array}$ \\
\hline
\end{tabular}




\subsubsection{Vanadium}

The raw material for producing vanadium powder is vanadium oxide $\mathrm{V}_{2} \mathrm{O}_{5}$. The immediate use of pentaoxide is impossible, since the reaction of its calcium hydride reduction proceeds with an explosion. Therefore, first $\mathrm{V}_{2} \mathrm{O}_{5}$ is reduced with hydrogen to $\mathrm{V}_{2} \mathrm{O}_{3}$, and then that to vanadium with $\mathrm{V}_{2} \mathrm{O}_{3}$ calcium hydride [4]. Properties of the obtained vanadium powders are listed in Table 3.

\subsubsection{Niobium}

Calciothermic niobium powders were obtained by calcium hydride reduction of niobiumpentoxide [23] and reducing $\mathrm{Ca}$ in the $\mathrm{CaCl}_{2}$ melt [57-58]. The original powders of niobium pentoxide $\mathrm{Nb}_{2} \mathrm{O}_{5}$ had some differences in the content of impurities, crystal structure, and specific surface area, which led to a spread in composition and properties of the final reduction products, i.e. niobium powders (Table 3 ).

\subsubsection{Tantalum}

The calciothermic reduction of tantalum from its oxide has been studied in the works [12, 47, 58-59, 66-67].

In the earliest work [47], tantalum was obtained by calcium reduction of its pentoxide in a bomb. Sulfur was added to the initial charge as a catalyst; this lowered the reduction temperature. Ta powder contained a significant amount of impurities (Table 3) and was intended for the production of ingots by bombardment melting, in which the content of impurities was significantly decreased.

\subsubsection{Chromium}

The composition and properties of chromium powder obtained by calcium hydride reduction of $\mathrm{Cr}_{2} \mathrm{O}_{3}$ are tabulated in Table 3 [4].

\subsubsection{Yttrium}

In [60], the fundamental possibility of reducing $\mathrm{YF}_{3}$ with calcium was established. The reduction was performed using the Kroll process in a molybdenum container. The reduction of yttrium fluoride took place completely, but the final product, metal yttrium, has included significant irregular molybdenum impurities, formed because of yttrium interaction with the walls of molybdenum container. The content of other impurities may be found in Table 3.

\subsubsection{REM}

Information about making, composition and properties of calciothermic powders of various REM is also contained in [43, 68].

\subsection{Intermetallic compounds}

\subsubsection{Titanium-aluminium system}

$\mathrm{Ti}_{3} \mathrm{Al}, \mathrm{TiAl}, \mathrm{TiAl}_{3}$ aluminides were obtained by the Kroll process through the reduction of a mixture of $\mathrm{TiO}_{2}$ and $\mathrm{Al}_{2} \mathrm{O}_{3}$ powders with calcium melt or vapor, by reducing $\mathrm{Ca}$ from a $\mathrm{CaCl}_{2}$ melt, by the calcium hydride method [43, 68, 69]. The latter is recommended as the most handy and productive. The particle size of aluminide powders, the content of oxygen and calcium in them are tabulated in Table 4.

The same opinion about the prospects of the calcium hydride method application for producing TiAl powder was reached in [4].

\subsubsection{Titanium-nickel system}

In [70, 71], a process of joint sintering and calcium vapor reducing a prepressed mixture of nickel and titanium hydride powders from a calcium melt was studied. Calcium vapors are used to remove oxygen both being present in the initial powders and appearing during the mixing and pressing of powders. The final product was a compact, the properties of which are shown in Table 4. Conditions for obtaining a single-phase TiNi powder by calcium hydride method are presented in [72]. It is shown that the mechanical and functional properties of TiNi calcium hydride intermetallic compound can be significantly improved by thermo-deformation treatment [73, 74].

\subsubsection{Titanium-chromium system}

Powder of $\mathrm{TiCr}_{2}$ intermetallic compound was manufactured by the reduction of a mixture of chromium oxide and titanium powders with calcium melted in $\mathrm{CaCl}_{2}$. The final powder comprises the agglomerates consisting of sintered $\mathrm{TiCr}_{2}$ particles of size up to $10 \mu \mathrm{m}$. The size of $\mathrm{TiCr}_{2}$ particles has depended on that of the original oxides. The resulting powders are recommended as hydrogen absorbers $[39,75,76]$.

\subsubsection{Titanium-iron system}

Synthesis of powders of TiFe intermetallic compound was performed in the process of calciothermic reduction of $\mathrm{TiO}_{2}$ or $\mathrm{FeTiO}_{3}$ (ilmenite) powders with calcium in the mode of self-propagating high-temperature synthesis (SHS) [77] or with calcium hydride [78]. A hydrogen absorption capacity was determined for the resulting powders, and they were additionally alloyed with $\mathrm{Zr}, \mathrm{Cr}, \mathrm{Mn}$, $\mathrm{Ni}$, and $\mathrm{Cu}$ in order to increase it [78].

\subsubsection{Niobium-aluminium system}

In [79], powder of $\mathrm{NbAl}_{3}$ intermetallic compound was obtained by the Kroll process using $\mathrm{Nb}_{2} \mathrm{O}_{5}$ reduction with calcium melt. The powder particles of an equiaxed roundish shape were several micrometers in size and contained about $0.15 \mathrm{wt} \%$ of oxygen. In [79, 87] there has been established the reduction conditions under which it is also possible to obtain single-phase $\mathrm{Nb}_{3} \mathrm{Al}$ and $\mathrm{Nb}_{2} \mathrm{Al}$ powders.

\subsubsection{Niobium-tin system}

The $\mathrm{Nb}_{3} \mathrm{Sn}$ superconducting phase powder is obtained by $\mathrm{Ca}$ or $\mathrm{Mg}$ vapor reduction from a mixture of $\mathrm{Nb}_{2} \mathrm{O}_{5}$ and $\mathrm{SnO}_{2}$ or $\mathrm{NbCl}_{5}$ and $\mathrm{SnCl}_{2} \cdot \mathrm{H}_{2} \mathrm{O}$ powders. The powder has 
Table 4.

Properties of calciothermic powders of intermetallic compounds

\begin{tabular}{|c|c|c|c|c|c|c|c|c|c|}
\hline \multirow{2}{*}{ No. } & \multirow{2}{*}{ Original charge } & \multirow{2}{*}{$\begin{array}{l}\text { Basic } \\
\text { phase }\end{array}$} & \multirow{2}{*}{$\begin{array}{l}\text { Alloying } \\
\text { addi- } \\
\text { tives }\end{array}$} & \multicolumn{5}{|c|}{ Impurities, wt\% } & \multirow{2}{*}{$\begin{array}{c}\text { Properites } \\
d_{a v}, \mu \mathrm{m}\end{array}$} \\
\hline & & & & 0 & C & $\mathrm{H}$ & $\mathrm{Ca}$ & The rest & \\
\hline 1 & $\begin{array}{l}\mathrm{TiO}_{2}, \mathrm{Al}_{2} \mathrm{O}_{3}, \mathrm{TiCl}_{4}, \mathrm{AlCl}_{2}, \\
\mathrm{Al}_{2}(\mathrm{SO})_{3}, \mathrm{CaH}_{2} \text { powders }\end{array}$ & $\begin{array}{l}\mathrm{Ti}_{3} \mathrm{Al} \text { or } \\
\mathrm{TiAl} \text { or } \\
\mathrm{TiAl}_{3}\end{array}$ & - & $0.1-0.2$ & - & - & 0.02 & - & 5 \\
\hline 2 & $\begin{array}{l}\mathrm{TiO}_{2}, \mathrm{Al}_{2} \mathrm{O}_{3}, \mathrm{CaH}_{2} \text { pow- } \\
\text { ders }\end{array}$ & TiAl & - & - & 0.07 & - & 0.15 & $\mathrm{Fe}-0.2$ & $<100$ \\
\hline 3 & $\mathrm{Ni}, \mathrm{TiH}_{2}, \mathrm{CaH}_{2}$ powders & $\mathrm{TiNi}$ & - & - & - & - & - & & - \\
\hline 4 & $\mathrm{TiO}_{2}, \mathrm{Ni}, \mathrm{CaH}_{2}$ powders & $\mathrm{TiNi}$ & - & - & 0.07 & - & 0.3 & $\mathrm{Fe}-0.2$ & $1-100$ \\
\hline 5 & $\begin{array}{l}\mathrm{TiO}_{2}, \mathrm{Cr}_{2} \mathrm{O}_{3} \text { powders, } \\
\text { Ca granules }\end{array}$ & $\mathrm{TiCr}_{2}$ & - & $\begin{array}{c}0.10- \\
0.15\end{array}$ & - & - & - & - & $5-10$ \\
\hline 6 & $\begin{array}{l}\mathrm{TiO}_{2} \\
\mathrm{Fe}, \mathrm{Fe}_{2} \mathrm{O}_{3} \text { powders, } \\
\text { Ca granules }\end{array}$ & TiFe & - & - & - & - & - & - & 8 \\
\hline 7 & $\begin{array}{l}\mathrm{FeTiO}_{3} \text { (ilmenite), } \mathrm{CaH}_{2} \\
\mathrm{CaCl}_{2}, \mathrm{TiO}_{2}, \mathrm{Fe} \text { powders }\end{array}$ & TiFe & $\begin{array}{l}\mathrm{Zr}, \mathrm{Cr} \\
\mathrm{Mn}, \mathrm{Ni} \\
\mathrm{Cu}\end{array}$ & - & - & - & - & $\mathrm{Ti}_{4} \mathrm{Fe}_{2} \mathrm{O}, \mathrm{TiFe}_{2}$ & $50-100$ \\
\hline 8 & $\begin{array}{l}\mathrm{ZrO}_{2}, \mathrm{Al}_{2} \mathrm{O}_{3}, \mathrm{CaH}_{2} \\
\text { powders }\end{array}$ & $\mathrm{Zr}_{3} \mathrm{Al}_{2}$ & - & 0.35 & 0.01 & - & - & $\mathrm{N}-0.02$ & $<63$ \\
\hline 9 & $\begin{array}{l}\mathrm{Nb}_{2} \mathrm{O}_{5} \text {, Al powders, } \\
\text { Ca granules }\end{array}$ & $\mathrm{NbAl}_{3}$ & - & 0.15 & - & - & - & - & $<10$ \\
\hline 10 & $\begin{array}{l}\mathrm{Nb}_{2} \mathrm{O}_{5}, \mathrm{SnO}_{2}, \mathrm{NbCl}_{5}, \\
\mathrm{SnCl}_{2} \cdot \mathrm{H}_{2} \mathrm{O} \text { powders, } \\
\text { Ca granules }\end{array}$ & $\mathrm{Nb}_{3} \mathrm{Sn}$ & - & - & - & - & - & - & $<1$ \\
\hline 11 & $\begin{array}{l}\mathrm{Y}_{2} \mathrm{O}_{3} \text {, Co powders, } \\
\mathrm{Ca} \text { granules }\end{array}$ & $\mathrm{YCo}_{5}$ & - & - & - & - & - & - & 20 \\
\hline 12 & $\begin{array}{l}\mathrm{Y}_{2} \mathrm{O}_{3} \text {, Ni powders, } \\
\text { Ca granules }\end{array}$ & $\mathrm{YNi}_{5}$ & - & - & - & - & - & - & $2-10$ \\
\hline 13 & $\begin{array}{l}\mathrm{La}_{2} \mathrm{O}_{3}, \mathrm{Ni} \text { powders; } \mathrm{Ca} \text {, } \\
\mathrm{CaH}_{2}, \mathrm{Al}_{2} \mathrm{O}_{3}, \mathrm{CeO} \text { gran- } \\
\text { ules }\end{array}$ & $\mathrm{LaNi}_{5}$ & $\begin{array}{l}\text { Co, } \mathrm{Al}, \\
\mathrm{Ce}\end{array}$ & $0.3-0.4$ & $0.03-0.06$ & $0.1-0.2$ & $0.1-0.2$ & $0.1-0.2$ & $3-160$ \\
\hline 14 & $\begin{array}{l}\text { Glycine solution; } \mathrm{CaH}_{2} \\
\mathrm{LiCl} ; \mathrm{La}_{2} \mathrm{O}_{3} \text { powder }\end{array}$ & $\mathrm{LaNi}_{5}$ & - & - & - & - & - & - & $\begin{array}{l}d=300- \\
500 \mathrm{~nm} ; \\
I=6-10 \mu \mathrm{m} \\
\quad \text { (rods) }\end{array}$ \\
\hline 15 & $\begin{array}{l}\mathrm{La}_{2} \mathrm{O}_{3} \text { powder, carbonyl } \\
\text { Fe powder, Si powder, } \\
\text { Ca granules }\end{array}$ & $\begin{array}{l}\mathrm{LaFe}_{13-} \\
\mathrm{Si}_{x}\end{array}$ & Si & - & - & - & - & - & 10 \\
\hline 16 & $\begin{array}{l}\mathrm{Sm}_{2} \mathrm{O}_{3} \text {, Fe powders, } \\
\mathrm{Ca} \text { granules }\end{array}$ & $\mathrm{Sm}_{2} \mathrm{Fe}_{17}$ & $\mathrm{~N}$ & $<0.13$ & - & - & - & - & 2 \\
\hline 17 & $\mathrm{Sm}_{2} \mathrm{O}_{3}$, Co $\mathrm{CaH}_{2}$ powders & $\begin{array}{l}\mathrm{SmCo}_{5} \\
\mathrm{Sm}_{2} \mathrm{Co}_{7}\end{array}$ & - & $\begin{array}{c}0.30- \\
0.42\end{array}$ & $0.02-0.04$ & - & $0.11-0.18$ & $\begin{array}{l}\text { Fe-0.09-0.18, } \\
\text { Si-0.01-0.03 }\end{array}$ & - \\
\hline 18 & $\begin{array}{l}\mathrm{Nd}_{2} \mathrm{O}_{3}, \mathrm{Fe}\left(\mathrm{NO}_{3}\right)_{3}, \\
\left(\mathrm{NH}_{4}\right)_{2} \mathrm{MoO}_{2}, \mathrm{CaH}_{2}\end{array}$ & $\mathrm{NdFe}_{10} \mathrm{Mo}_{2}$ & - & - & - & - & - & $\begin{array}{c}\text { Sum of } \\
\text { impurities } 1.4 \%\end{array}$ & $5-10$ \\
\hline 19 & $\begin{array}{l}\mathrm{Nd}_{2} \mathrm{O}_{3}, \mathrm{Fe}_{2} \mathrm{O}_{3} ; \mathrm{Ca} \text { granules; } \\
\mathrm{FeB}, \mathrm{FeCl}_{2} \cdot 4 \mathrm{H}_{2} \mathrm{O}, \mathrm{NdBH}_{4}\end{array}$ & $\mathrm{Nd}_{2} \mathrm{Fe}_{14} \mathrm{~B}$ & - & - & - & - & - & - & $1-100$ \\
\hline 20 & $\begin{array}{l}\mathrm{NdCl}_{3} ; \mathrm{Fe}, \mathrm{Ti}, \mathrm{FeB} \text { powders, } \\
\mathrm{Ca}, \mathrm{NaN}_{3} \text { granules }\end{array}$ & $\begin{array}{c}\mathrm{NdFe}_{11} \mathrm{Ti} \\
\mathrm{NdFe}_{11} \mathrm{TiN}_{x}\end{array}$ & - & $0.4-0.7$ & - & - & - & $\begin{array}{c}\mathrm{N}-0.02 \\
\alpha-\mathrm{Fe}-2.2 \\
\mathrm{~N}-0.34-1.34 \\
\alpha-\mathrm{Fe}-9.7-39.5\end{array}$ & - \\
\hline
\end{tabular}




\begin{tabular}{|c|c|c|}
\hline Others & Method of making & Source \\
\hline- & $\begin{array}{l}\text { Kroll process, Calcium hydride } \\
\text { method, Ca reduction from a } \mathrm{CaCl}_{2} \text { melt }\end{array}$ & {$[43,68-69]$} \\
\hline $\begin{array}{l}\text { Bulk density } 1.2-1.4 \mathrm{~g} / \mathrm{cm}^{3}, \text { microhardness } \\
\text { of particles } 2.7 \pm 0.4 \mathrm{GPa}\end{array}$ & Calcium hydride method & [4] \\
\hline- & Ca vapor reduction of $\mathrm{Ni}+\mathrm{TiH}_{2}$ mixture & [70-72] \\
\hline $\begin{array}{l}\text { Microhardness of particles } 5.6 \pm 0.6 \mathrm{GPa} \text {, } \\
\text { bulk density } 1.4-1.6 \mathrm{~g} / \mathrm{cm}^{3}\end{array}$ & Calcium hydride reduction & [4] \\
\hline- & $\mathrm{Ca}$ reduction from $\mathrm{a} \mathrm{CaCl}{ }_{2}$ melt & {$[39,75-76]$} \\
\hline- & $\begin{array}{l}\text { Synthesis in a self-propagating high-temperature } \\
\text { synthesis (SHS) mode }\end{array}$ & {$[77]$} \\
\hline- & Calcium hydride reduction & [78] \\
\hline $\begin{array}{l}\mathrm{H} \text { absorption capacity }-31.2, \mathrm{CO} \text { absorption } \\
\text { capacity }-0.511 \mathrm{~L} / \mathrm{Pa}, \mathrm{S}_{s p}=0.11-0.12 \mathrm{~m}^{2} / \mathrm{g}\end{array}$ & Calcium hydride reduction & [4] \\
\hline- & Kroll process & [79] \\
\hline $\begin{array}{l}\text { Temperature of transition to superconducting } \\
\text { state }-255^{\circ} \mathrm{C}(18.0 \mathrm{~K})\end{array}$ & Ca vapor reduction & [49] \\
\hline- & Reduction by the CRD method & [25] \\
\hline Measured are some magnetic properties & Reduction by the CRD method & [28] \\
\hline Bulk density $3.45-3.55 \mathrm{~g} / \mathrm{cm}^{3}$, fluidity $30-40 \mathrm{~s}$ & Calcium hydride method & {$[4,19,80-81]$} \\
\hline- & Solid-phase reduction of $\mathrm{CaH}_{2}$ & [82] \\
\hline Measured are some magnetic properties & Reduction by the RD method & [30] \\
\hline Measured are some magnetic properties & $\begin{array}{l}\text { Nitriding up to a } \mathrm{Sm}_{2} \mathrm{Fe}_{17} \mathrm{~N}_{3} \text { composition after } \\
\text { reduction }\end{array}$ & {$[4,18,20,80,82]$} \\
\hline- & Calcium hydride method & [4] \\
\hline - & $\begin{array}{l}\text { Calcium hydride } \\
\text { method }\end{array}$ & {$[22,26]$} \\
\hline Measured are some magnetic properties & Reduction by the CRD method (with the use of $\mathrm{Ca}$ or $\mathrm{CaH}_{2}$ ) & [83-86] \\
\hline & Reduction of Ca by the CRD method & [26] \\
\hline ed are some magnetic $p$ & $\begin{array}{l}\text { Reduction of Ca by the CRD method and consequent } \\
\text { nitriding }\end{array}$ & [26] \\
\hline
\end{tabular}


required careful washing from the reaction products and contained impurities of oxides and nitrides. The particles of $\mathrm{Nb}_{3} \mathrm{Sn}$ powder measured less than $1 \mu \mathrm{m}$ and had a relatively low temperature of transition to the superconducting state $\left(-255^{\circ} \mathrm{C}\right.$ or $\left.18.0 \mathrm{~K}\right)$.

\subsubsection{Zirconium-aluminium system}

The powder, which is a mixture of particles of $\mathrm{Zr}_{3} \mathrm{Al}$, $\mathrm{Zr}_{5} \mathrm{Al}_{3}, \mathrm{Zr}_{3} \mathrm{Al}_{2}$ high-temperature phases, was obtained by the Kroll method through $\mathrm{Ca}$ reducing the mixture of $\mathrm{ZrO}_{2}$ and $\mathrm{Al}_{2} \mathrm{O}_{3}$ powders with calcium cuttings [4, 88]. Composition and properties of the powders are shown in Table 4. The main function of the powders is gas absorption (getters).

\subsubsection{Yttrium-cobalt system}

Powder of $\mathrm{YCo}_{5}$ intermetallic compound was produced by $\mathrm{Y}_{2} \mathrm{O}_{3}$ calcium reduction through the CRD method [25]. After final refinement from the reaction products, $\mathrm{YCo}_{5}$ powder contained 15 at $\% \mathrm{Y}$ and 75 at $\% \mathrm{Co}$, the main impurity was $\mathrm{CaO}$. The powder particles had a complex spongy shape. The particle size is about $20 \mu \mathrm{m}$.

\subsubsection{Yttrium-nickel system}

Powder of $\mathrm{YNi}_{2}$ intermetallic compound was made through calcium reduction of $\mathrm{Y}_{2} \mathrm{O}_{3}$ by the CRD method [28]. The powder contained 20 at $\% \mathrm{Y}$ and 70 at $\% \mathrm{Ni}$; the rest were impurities of $\mathrm{CaO}, \mathrm{Ca}$ and $\mathrm{O}$. The powder particles were of a sophisticated sponge shape; the particle size was $2-10 \mu \mathrm{m}$. Magnetic properties of the powder one can find in Table 4.

\subsubsection{Lanthanum-nickel system}

Powders of well-known hydrogen sorbents based on $\mathrm{LaNi}_{5}$ intermetallic compound were obtained and studied in the works $[4,18,19,80-82]$. The properties of the $\mathrm{LaNi}_{5}$-based powders obtained by the calcium hydride method are studied in depth [4, 18, 80-81] (Table 4). Alloying of these powders with $\mathrm{Co}, \mathrm{Al}$ and $\mathrm{Ce}$ allows to change the hydrogen capacity within the limits of 146$170 \mathrm{~cm}^{3} / \mathrm{g}$ and to widely vary the dissociation pressure at temperatures of $20-100{ }^{\circ} \mathrm{C}$.

Fine $\mathrm{LaNi}_{5}$ powders were obtained by the original calciothermic method of solid-phase reduction from a mixture of glycine-containing complex solutions with calcium hydride and lithium chloride [82].

\subsubsection{Lanthanum-iron system}

In [89], the silicon content influence on manufacturing and properties of calciothermic powder of $\mathrm{LaFe}_{13}$ intermetallic compound, used as a permanent magnet, has been studied. The $\mathrm{LaFe}_{13-x} \mathrm{Si}_{x}$ powder was produced by the RD method. The average size of the powder particles was $10 \mu \mathrm{m}$. The structure of the powder particles is singlephase with a homogeneous distribution of all elements. Changes in the silicon content do not affect the size of the particles or their morphology.

\subsubsection{Samarium-iron system}

Powders of $\mathrm{Sm}_{3} \mathrm{Fe}_{17}$ intermetallic compound, which are promising magnetic materials, were obtained mainly by the RD-method of solid-phase calciothermic reduction in the works [4, 18, 20, 19, 80-82]. Following the reduction, the obtained porous $\mathrm{Sm}_{3} \mathrm{Fe}_{13}$ samples were ground to the particles of $\sim 2 \mu \mathrm{m}$ in size and then nitrided at $450{ }^{\circ} \mathrm{C}$ in ammonia until they were completely converted to the Sm${ }_{3} \mathrm{Fe}_{13} \mathrm{~N}_{3}$ phase. On grinding, the size of the particles has decreased with increasing time, and the oxygen content in them has increased. Magnetic properties were improved by reducing particle size, while increasing oxygen made them worse.

\subsubsection{Samarium-cobalt system}

Powders based on $\mathrm{SmCo}_{5}$ and $\mathrm{Sm}_{2} \mathrm{Co}_{17}$ intermetallic compounds are used for manufacturing permanent magnets. These powders are obtained by the calcium hydride method [4] reducing a mixture of $\mathrm{Sm}_{2} \mathrm{O}_{3}$, Co powders and $\mathrm{CaH}_{2}$ cuttings. The powders of $\mathrm{Co}-37 \mathrm{Sm}$ and $\mathrm{Co}-$ $41 \mathrm{Sm}$ (wt\%) compositions based on $\mathrm{SmCo}_{5}$ and $\mathrm{Sm}_{2} \mathrm{Co}_{17}$ phases respectively, have gained acceptance. As a result of calciothermic reduction and subsequent refinement, both sorts of powders also contain $\mathrm{Sm}_{5} \mathrm{Co}_{19}$ intermetallic compound as an impurity; it is further decomposed into $\mathrm{SmCo}_{5}$ and $\mathrm{Sm}_{2} \mathrm{Co}_{17}$ on heat treatment in the production of permanent magnets. Powders contain 0.30-0.42 wt\% of oxygen and small admixtures of carbon, calcium, iron and silicon (Table 4).

\subsubsection{Neodymium-iron-molybdenum system [22]}

To make $\mathrm{NdFe}_{10} \mathrm{Mo}_{2}$ intermetallic compound by calciothermic method, there was used the initial mixture of $\mathrm{Nd}_{2} \mathrm{O}_{3}, \mathrm{Fe}\left(\mathrm{NO}_{3}\right)_{3} \cdot 9 \mathrm{H}_{2} \mathrm{O}$ and $\left(\mathrm{NH}_{4}\right)_{2} \mathrm{MoO}_{2}$ powders, which by means of a complex heat treatment was transferred into a mixture of $\mathrm{Fe}_{2} \mathrm{O}_{3}, \mathrm{NdFeO}_{3}$ and $\mathrm{Fe}_{2}\left(\mathrm{MoO}_{4}\right)_{3}$ fine powders. The latter was subjected to a calcium hydride reduction in which a single-phase powder of $\mathrm{NdFe}_{10} \mathrm{Mo}_{2}$ intermetallic compound with no more than $1.4 \%$ of impurities was formed whereby solid phase diffusion (Table 4). Sponge powders of $\mathrm{NdFe}_{10} \mathrm{Mo}_{2}$ up to $10 \mu \mathrm{m}$ in size have contained a small amount of oxygen, which can be easily lessened on subsequent vacuum remelting, that is for which the obtained powders were intended. The powders are promising as hard magnetic materials.

\subsubsection{Neodymium-iron-boron system}

Powders of hard magnetic $\mathrm{Nd}_{2} \mathrm{Fe}_{14} \mathrm{~B}$ intermetallic compound were obtained by solid phase diffusion RD using $\mathrm{Ca}$ or $\mathrm{CaH}_{2}$ as a reducing agent [83-86]. The $\mathrm{Nd}_{2} \mathrm{O}_{3}, \mathrm{Fe}_{2} \mathrm{O}_{3}, \mathrm{~B}_{2} \mathrm{O}_{3}$ powders, $\mathrm{Ca}$ granules, $\mathrm{CaFeB}$, $\mathrm{FeCl}_{2} \cdot 4 \mathrm{H}_{2} \mathrm{O}, \mathrm{NbCl}_{3} \cdot 6 \mathrm{H}_{2} \mathrm{O}, \mathrm{NdBH}_{4}, \mathrm{FeCl}_{3} \cdot 4 \mathrm{H}_{2} \mathrm{O}$ cuttings were used as starting substances in different works. By using powders of the initial substances of different dispersities, varying the conditions of reduction and refinement of the final powders from the reaction products, it was made possible to change the size of $\mathrm{Nd}_{2} \mathrm{Fe}_{14} \mathrm{~B}$ 
Table 5.

Properties of calcium hydride powders of transition metal carbides

\begin{tabular}{|c|c|c|c|c|c|c|c|c|c|c|}
\hline \multirow{2}{*}{ Powder } & \multicolumn{8}{|c|}{ Chemical composition, wt\% } & \multirow{2}{*}{ Phase composition } & \multirow{2}{*}{$\begin{array}{l}\text { Specific surface } S \text {, } \\
\mathrm{m}^{2} / \mathrm{g}\end{array}$} \\
\hline & $\mathrm{C}_{\text {tot }}$ & $\overline{C_{f r}}$ & $\mathrm{Ti}$ & $\mathrm{Zr}$ & $\mathrm{Hf}$ & $\mathrm{Cr}$ & $\mathrm{Ca}$ & 0 & & \\
\hline Titaium carbide & 20.02 & 0.03 & base & - & - & - & 0.05 & 0.3 & $\mathrm{TiC}_{1.0}$ & $1.8-3.2$ \\
\hline Zirconium carbide & 11.3 & 0.06 & - & base & - & - & 0.1 & 0.3 & $\mathrm{ZrC}_{1.0}$ & 1.2 \\
\hline Hafnium carbide & 6.2 & 0.06 & - & - & base & - & - & 0.3 & $\mathrm{HfC}_{1.0}$ & 0.6 \\
\hline $\begin{array}{l}\text { Chromium } \\
\text { carbide }\end{array}$ & 10.9 & 0.06 & - & - & - & base & 0.1 & 0.3 & $\begin{array}{l}\mathrm{Cr}_{3} \mathrm{C}_{2}-50 \\
\mathrm{Cr}_{7} \mathrm{C}_{3}-50\end{array}$ & 1.4 \\
\hline
\end{tabular}

particles in the range from 1 to $100 \mu \mathrm{m}$, while their oxygen content has significantly increased as the particle sizes have decreased.

\subsubsection{5. $\mathrm{Nd}-\mathrm{Fe}-\mathrm{Ti}$ and $\mathrm{Nd}-\mathrm{Fe}-\mathrm{Ti}-\mathrm{N}$ systems}

Powders of promising hard magnetic $\mathrm{NdFe}_{11} \mathrm{Ti}$ and $\mathrm{NdFe}_{11} \mathrm{TiN}_{y}$ intermetallic compounds were obtained in [26] using different variants of the CRD solid phase diffusion methods. When obtaining $\mathrm{NdFe}_{11} \mathrm{Ti}$, the original materials were $\mathrm{NdCl}_{3}$, powders of $\mathrm{Fe}, \mathrm{Ti}, \mathrm{FeB}$ and granules of $\mathrm{Ca}$. $\mathrm{NdFe}_{11}$ Ti alloys can be saturated with nitrogen when they interact with sodium nitrogen $\left(\mathrm{Na}_{3} \mathrm{~N}\right)$ at $450^{\circ} \mathrm{C}$. In this case, the $\mathrm{NdFe}_{11} \mathrm{TiN}_{y}$ intermetallic compound is formed, and a layer of soft magnetic $\alpha-\mathrm{Fe}$ is formed at the grain boundaries of this phase. Compositions of magnetic phases and some of their properties are tabulated in Table 4.

\subsection{Refractory compounds}

\subsubsection{Carbides}

Calciothermic reduction of rare metal oxides with formation of refractory carbides takes place on heat treatment of $\mathrm{MeO}, \mathrm{CaC}_{2}$ and $\mathrm{CaH}_{2}$ mixtures.

Calcium carbide $\mathrm{CaC}_{2}$ is a strong reducing agent, and from a thermodynamic point of view, it is able to both reduce oxides of rare metals and lead to the formation of their carbides at the same time. However, even G. A. Meerson and his colleagues in the early works [90-91] have not met with success in their attempts to obtain stoichiometric, oxygen-free titanium carbide at temperatures less than $1300^{\circ} \mathrm{C}$ in this way. Similar results were also obtained by calcium and graphite reduction of rutile powder at temperatures up to $950{ }^{\circ} \mathrm{C}$, when the powders of non-stoichiometric titanium carbide $10 \mu \mathrm{m}$ in size were obtained [92].

The mixture of calcium carbide and calcium hydride turned out to be the most interesting and promising reducing agent and carbidizer in this system [4, 49, 93-95].

Properties of refractory carbides obtained with the use of $\mathrm{CaC}_{2}$ and $\mathrm{CaH}_{2}$ by means of their reduction and carbidization from corresponding oxides are represented in Table 5 [4]. Fig. 14 demonstrates typical outward appearance of the particles of carbide $\mathrm{ZrC}$.
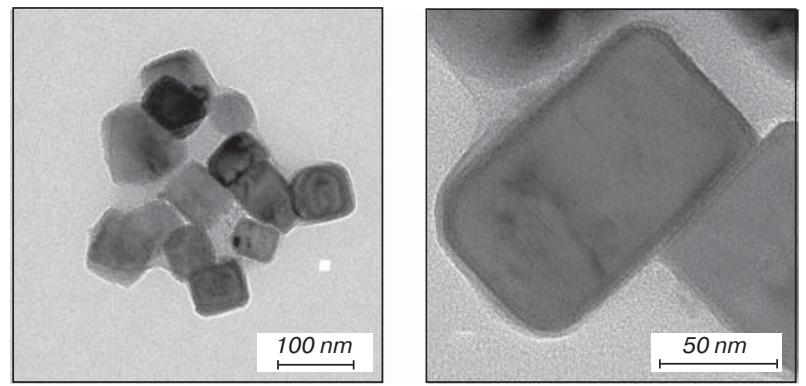

Fig. 14. Characteristic morphology of the particles of $\mathrm{ZrC}$ powder obtained by calcium hydride method

\subsubsection{Nitrides}

Manufacturing of refractory nitrides by calciothermic reduction of oxides of rare metals comprises two stages. At the first stage, powder of the metal is obtained by calcium hydride method according to the technology described above, at the second one this powder is nitrided in nitrogen medium at temperatures of $1000-1200{ }^{\circ} \mathrm{C}$; the formation of nitride is limited by solid phase nitrogen diffusion into the metal with arising of nitrides. The particles of nitrides are of irregular shape with the size from to $100 \mu \mathrm{m}$. The average size $d_{a v} \sim 40 \mu \mathrm{m}$.

Depending on duration and temperature of nitriding, the nitrogen concentration in a nitride grows and practically reaches the stoichiometric value.

Chemical and phase composition of the powders of nitrides of titanium, zirconium and chromium are tabulated in Table 6 [4].

\subsection{Composite materials}

Powders of composite materials are a pool of particles, each presenting the composite material in miniature. In addition, the particles consist of two or more phases that have different functional purposes.

Table 6 .

Content and particle sizes of calcium hydride powders of transition metal nitrides [4]

\begin{tabular}{|c|c|c|c|c|c|c|c|c|}
\hline \multirow{2}{*}{ Powder } & \multicolumn{6}{|c|}{ Chemical composition, wt\% } & \multirow{2}{*}{$\begin{array}{c}\text { Phase } \\
\text { composition }\end{array}$} & \multirow{2}{*}{$\begin{array}{l}d_{a v} \\
\mu \mathrm{m}\end{array}$} \\
\hline & $\overline{\mathrm{Ti}}$ & $\mathrm{Zr}$ & $\mathrm{Cr}$ & $N$ & $\mathrm{O}$ & $\mathrm{Ca}$ & & \\
\hline Titanium nitride & base & - & - & 23.5 & 0.1 & 0.08 & $\mathrm{TiN}_{1.0}$ & \\
\hline Zirconium nitride & - & base & - & 13.2 & 0.1 & 0.07 & $\mathrm{ZrN}_{1.0}$ & $40-63$ \\
\hline Chromium nitride & - & - & base & 11.7 & 0.1 & 0.10 & $\mathrm{Cr}_{2} \mathrm{~N}$ & \\
\hline
\end{tabular}


Calcium hydride reduction makes it possible to obtain powders of composite materials consisting of both coated particles and the particles dispersion reinforced by internal nitriding or carbidization [4, 96, 97]. Technologically, it is convenient to carry out these processes in one apparatus in two stages. At the first stage, the technology described above is used to obtain the particles of metals or intermetallic compounds. At the second stage, one should implement an external or internal saturation after the introduction of nitrogen, carbon or gases containing them into the system, that is, obtain either particles coated with nitrides and carbides, or the ones dispersion reinforced by nitrides or carbides precipitations.

Examples of obtaining the powders of composite materials by calcium hydride reduction followed by nitriding or carbidization will be given below.

Table 7.

Charge components and nitriding modes of experimental metal nitride powdered alloys [4]

\begin{tabular}{|c|c|c|c|}
\hline No. & Material designation & Charge components & Nitriding mode \\
\hline 1 & $\mathrm{TiN}-\mathrm{Ni}$ & $\mathrm{TiO}_{2}+\mathrm{Ni}+\mathrm{CaH}_{2}$ & $1200^{\circ} \mathrm{C}, 11 \mathrm{~h}$ \\
\hline 2 & $\mathrm{Ni}_{3} \mathrm{Al}-\mathrm{TiN}$ & $\mathrm{TiO}_{2}+\mathrm{Al}_{2} \mathrm{O}_{3}+\mathrm{Ni}+\mathrm{CaH}_{2}$ & $1200^{\circ} \mathrm{C}, 8 \mathrm{~h}$ \\
\hline 3 & $\mathrm{NiAl}-\mathrm{TiN}$ & $\mathrm{TiO}_{2}+\mathrm{Al}_{2} \mathrm{O}_{3}+\mathrm{Ni}+\mathrm{CaH}_{2}$ & $1200^{\circ} \mathrm{C}, 8 \mathrm{~h}$ \\
\hline 4 & $\mathrm{TiN}-\mathrm{TiAl}$ & $\mathrm{TiO}_{2}+\mathrm{Al}_{2} \mathrm{O}_{3}+\mathrm{CaH}_{2}$ & $1200^{\circ} \mathrm{C}, 10 \mathrm{~h}$ \\
\hline 5 & $\mathrm{TiN}-\mathrm{Ni}_{3} \mathrm{Al}$ & $\mathrm{TiO}_{2}+\mathrm{Al}_{2} \mathrm{O}_{3}+\mathrm{Ni}+\mathrm{CaH}_{2}$ & $1200^{\circ} \mathrm{C}, 12 \mathrm{~h}$ \\
\hline 6 & $\mathrm{TiN}-\mathrm{Ti}_{2} \mathrm{Ni}$ & $\mathrm{TiO}_{2}+\mathrm{Ni}+\mathrm{CaH}_{2}$ & $1200^{\circ} \mathrm{C}, 12 \mathrm{~h}$ \\
\hline 7 & $\begin{array}{c}\text { Nichrome } \\
(80 / 20 w t \%)-\left(\mathrm{Cr}_{2} \mathrm{~N}+\mathrm{CrN}\right)\end{array}$ & $\mathrm{Cr}_{2} \mathrm{O}_{3}+\mathrm{Ni}+\mathrm{CaH}_{2}$ & $1050^{\circ} \mathrm{C}, 5 \mathrm{~h}$ \\
\hline 8 & $\begin{array}{c}\text { Nichrome } \\
(70 / 30 w t \%)-\mathrm{Cr}_{2} \mathrm{~N}\end{array}$ & $\mathrm{Cr}_{2} \mathrm{O}_{3}+\mathrm{Ni}+\mathrm{CaH}_{2}$ & $1100^{\circ} \mathrm{C}, 4 \mathrm{~h}$ \\
\hline 9 & $(\mathrm{AIN}+\mathrm{TiN})-\mathrm{Ni}$ & $\mathrm{TiO}_{2}+\mathrm{Al}_{2} \mathrm{O}_{3}+\mathrm{Ni}+\mathrm{CaH}_{2}$ & $\begin{array}{l}1100-1200^{\circ} \mathrm{C}, 5 \mathrm{~h} \\
1340-1380^{\circ} \mathrm{C}, 5 \mathrm{~h}\end{array}$ \\
\hline
\end{tabular}

\subsubsection{Composite metal nitride powders [4]}

Experimental composite metal nitride powders were obtained by calcium hydride recovery with subsequent nitriding. The reduction process was carried out using the technology and in the apparatus described in Section 3. After the reduction was completed, nitrogen was fed into the same device, and nitriding was performed according to the modes shown in Table 7. The composition and properties of the obtained experimental composite powders are listed in Table 8 and Table 9. All powders had a complex, spongy structure of the particles.

The shape and size of the powder particles are typical for the powders obtained by the calcium hydride method. Fig. 15 shows a photo of the $\mathrm{Ni}_{3} \mathrm{Al}-\mathrm{TiN}$ powder particles after nitriding. The microhardness of nitride phases and

Table 8.

Chemical and phase composition of nitride-containing experimental composite powders

\begin{tabular}{|c|c|c|c|c|c|c|c|c|c|c|c|c|}
\hline \multirow{3}{*}{ No. } & \multirow{3}{*}{$\begin{array}{l}\text { Material desig- } \\
\text { nation }\end{array}$} & \multicolumn{10}{|c|}{ Chemical composition, wt $\%$} & \multirow{3}{*}{$\begin{array}{l}\text { Phase composition, } \\
\text { wt } \%\end{array}$} \\
\hline & & \multicolumn{5}{|c|}{ Main elements } & \multicolumn{5}{|c|}{ Impurities } & \\
\hline & & $\mathrm{Ti}$ & $\mathrm{Ni}$ & $\mathrm{N}$ & $\mathrm{Cr}$ & $\mathrm{Al}$ & O & C & $\mathrm{Ca}$ & $\mathrm{Fe}$ & S & \\
\hline 1 & $\mathrm{TiN}-\mathrm{Ni}$ & base & 39.4 & 13.4 & - & - & 0.21 & 0.06 & 0.11 & 0.07 & $<0.01$ & $\mathrm{TiN} \sim 60 ; \mathrm{Ni} \sim 40$ \\
\hline 2 & $\mathrm{Ni}_{3} \mathrm{Al}-\mathrm{TiN}$ & 11.7 & base & 3.4 & - & 11.9 & 0.15 & 0.04 & 0.09 & 0.08 & $<0.01$ & $\mathrm{Ni}_{3} \mathrm{Al} \sim 85 ; \mathrm{TiN} \sim 15$ \\
\hline 3 & $\mathrm{NiAl}-\mathrm{TiN}$ & 23.2 & base & 6.7 & - & 26.6 & 0.14 & 0.05 & 0.07 & 0.09 & $<0.01$ & $\mathrm{NiAl} \sim 70 ; \mathrm{TiN} \sim 30$ \\
\hline 4 & TiN - TiAl & base & - & 15.8 & - & 11.4 & 0.24 & 0.06 & 0.08 & 0.06 & $<0.01$ & TiN 70; TiAl 30 \\
\hline 5 & $\mathrm{TiN}-\mathrm{Ni}_{3} \mathrm{Al}$ & base & 21.6 & 16.7 & - & 3.5 & 0.24 & 0.08 & 0.10 & 0.12 & $<0.01$ & $\mathrm{TiN} \sim 75 ; \mathrm{Ni}_{3} \mathrm{Al} \sim 25$ \\
\hline 6 & $\mathrm{TiN}-\mathrm{Ti}_{2} \mathrm{Ni}$ & base & 5.8 & 15.9 & - & - & 0.18 & 0.07 & 0.09 & 0.11 & $<0.01$ & $\mathrm{TiN} \sim 70 ; \mathrm{Ti}_{2} \mathrm{Ni} \sim 30$ \\
\hline 7 & $\begin{array}{c}\text { Nichrome } \\
(80 / 20 \text { wt. \%) - } \\
\left(\mathrm{Cr}_{2} \mathrm{~N}+\mathrm{CrN}\right)\end{array}$ & - & base & 4.3 & 38.4 & - & 0.14 & 0.05 & 0.12 & 0.08 & $<0.01$ & $\begin{array}{c}\text { Nichrome } \\
(80 / 20 \text { wt. \%) } \sim 70 \\
\mathrm{Cr}_{2} \mathrm{~N} \sim 20 ; \mathrm{CrN} \sim 10\end{array}$ \\
\hline 8 & $\begin{array}{c}\text { Nichrome } \\
\text { (70/30 wt.\%) } \\
-\mathrm{Cr}_{2} \mathrm{~N}\end{array}$ & - & base & 1.8 & 38.7 & - & 0.12 & 0.06 & 0.10 & 0.09 & $<0.01$ & $\begin{array}{c}\text { Nichrome } \\
\text { (70/30 wt.\%) 85; } \\
\mathrm{Cr}_{2} \mathrm{~N} \sim 15\end{array}$ \\
\hline 9 & $(\mathrm{AlN}+\mathrm{TiN})-\mathrm{Ni}$ & 15.2 & 19.8 & 24.9 & - & base & 0.22 & 0.08 & 0.06 & 0.12 & $<0.01$ & $\begin{aligned} \mathrm{AIN} & \sim 60 \\
\mathrm{TiN} & \sim 20 \\
\mathrm{Ni} & \sim 20\end{aligned}$ \\
\hline
\end{tabular}


Table 9.

Physical and processing behavior of experimental nitride-containing composite powders

\begin{tabular}{|c|c|c|c|c|}
\hline No. & Material designation & $\begin{array}{l}\text { Particle } \\
\text { size, } \mu \mathrm{m}\end{array}$ & $\begin{array}{l}\text { Microhardness of main } \\
\text { phases of alloy, GPa }\end{array}$ & $\begin{array}{l}\text { Bulk density, } \\
\mathrm{g} / \mathrm{cm}^{3}\end{array}$ \\
\hline 1 & $\mathrm{TiN}-\mathrm{Ni}$ & $1 \ldots 100$ & $\begin{aligned} \mathrm{TiN} & =19.7 \pm 0.6 \\
\mathrm{Ni} & =0.9 \pm 0.3\end{aligned}$ & 1.15 \\
\hline 2 & $\mathrm{Ni}_{3} \mathrm{Al}-\mathrm{TiN}$ & $1 \ldots 160$ & $\begin{array}{l}\mathrm{Ni}_{3} \mathrm{Al}=5.2 \pm 0.4 \\
\mathrm{TiN}=19.9 \pm 0.4\end{array}$ & 1.32 \\
\hline 3 & $\mathrm{NiAl}-\mathrm{TiN}$ & $1 \ldots 60$ & $\begin{array}{l}\mathrm{NiAl}=3.7 \pm 0.5 \\
\mathrm{TiN}=20.0 \pm 0.5\end{array}$ & 1.41 \\
\hline 4 & TiN - TiAl & $1 \ldots 60$ & $\begin{array}{c}\mathrm{TiAl}=2.8 \pm 0.5 \\
\mathrm{TiN}=19.6 \pm 0.6\end{array}$ & 1.28 \\
\hline 5 & $\mathrm{TiN}-\mathrm{Ni}_{3} \mathrm{Al}$ & $1 \ldots 60$ & $\begin{array}{c}\mathrm{TiN}=20.1 \pm 0.3 \\
\mathrm{Ni}_{3} \mathrm{Al}=4.9 \pm 0.4\end{array}$ & 1.24 \\
\hline 6 & $\mathrm{TiN}-\mathrm{Ti}_{2} \mathrm{Ni}$ & $1 \ldots 100$ & $\begin{array}{c}\mathrm{TiN}=20.1 \pm 0.3 \\
\mathrm{Ti}_{2} \mathrm{Ni}=11.7 \pm 0.3\end{array}$ & 1.23 \\
\hline 7 & $\begin{array}{c}\text { Nichrome } \\
(80 / 20 \text { wt. } \%)-\left(\mathrm{Cr}_{2} \mathrm{~N}+\mathrm{CrN}\right)\end{array}$ & $1 \ldots 160$ & $\begin{array}{c}\text { Nichrome }=1.8 \pm 0.3 \\
\mathrm{Cr}_{2} \mathrm{~N}=15.4 \pm 0.2 \\
\mathrm{CrN}=10.2 \pm 0.2\end{array}$ & 1.46 \\
\hline 8 & $\begin{array}{c}\text { Nichrome } \\
(70 / 30 \text { wt. } \%)-\mathrm{Cr}_{2} \mathrm{~N}\end{array}$ & $1 \ldots 160$ & $\begin{array}{c}\text { Nichrome }=2.3 \pm 0.4 \\
\mathrm{Cr}_{2} \mathrm{~N}=15.7 \pm 0.3\end{array}$ & 1.53 \\
\hline 9 & $(\mathrm{AIN}+\mathrm{TiN})-\mathrm{Ni}$ & $1 \ldots 160$ & $\begin{array}{c}\mathrm{AIN}=14.8 \pm 0.5 \\
\mathrm{TiN}=21.3 \pm 0.2 \\
\mathrm{Ni}=0.8 \pm 0.4\end{array}$ & 1.37 \\
\hline
\end{tabular}

Table 10

Charge components and modes of making of carbide-containing experimental composite powders

\begin{tabular}{|r|l|l|c|}
\hline No. & Material designation & \multicolumn{1}{c|}{$\begin{array}{c}\text { Charge components } \\
\text { Reduction- }\end{array}$} & $\begin{array}{c}\text { Redization mode } \\
\text { carbidizat }\end{array}$ \\
\hline 1 & $\mathrm{TiC}-\mathrm{Fe}(\mathrm{Ni}, \mathrm{Mo})$ & $\mathrm{TiO}_{2}+\mathrm{Fe}+\mathrm{Ni}+\mathrm{Mo}+\mathrm{CaC}_{2}+\mathrm{CaH}_{2}$ & $1150 \ldots 1200^{\circ} \mathrm{C}, 12 \mathrm{~h}$ \\
\hline 2 & $\left(\mathrm{Cr}_{3} \mathrm{C}_{2}+\mathrm{Cr}_{7} \mathrm{C}_{3}\right)-\mathrm{Ni}$ & $\mathrm{Cr}_{2} \mathrm{O}_{3}+\mathrm{Ni}+\mathrm{CaC}_{2}+\mathrm{CaH}_{2}$ & $1200^{\circ} \mathrm{C}, 10 \mathrm{~h}$ \\
\hline 3 & $\mathrm{TiC}-\mathrm{Ni}(\mathrm{Mo})$ & $\mathrm{TiO}_{2}+\mathrm{Ni}+\mathrm{Mo}+\mathrm{CaC}_{2}+\mathrm{CaH}_{2}$ & $1200^{\circ} \mathrm{C}, 10 \mathrm{~h}$ \\
\hline 4 & $\left(\mathrm{Cr}_{7} \mathrm{C}_{3}+\mathrm{TiC}\right)-\mathrm{Ni}(\mathrm{Mo})$ & $\mathrm{TiO}_{2}+\mathrm{Cr}_{2} \mathrm{O}_{3}+\mathrm{Ni}+\mathrm{Mo}+\mathrm{CaC}_{2}+\mathrm{CaH}_{2}$ & $1200^{\circ} \mathrm{C}, 10 \mathrm{~h}$ \\
\hline 5 & $\mathrm{TiC}_{-} \mathrm{Ni}_{3} \mathrm{Al}$ & $\mathrm{TiO}_{2}+\mathrm{Ni}+\mathrm{Mo}+\mathrm{Al}_{2} \mathrm{O}_{3}+\mathrm{CaC}_{2}+\mathrm{CaH}_{2}$ & $1200^{\circ} \mathrm{C}, 10 \mathrm{~h}$ \\
\hline 6 & $\mathrm{Cr}_{7} \mathrm{C}_{3}-\mathrm{Ni} \mathrm{Al}_{3}$ & $\mathrm{Cr}_{2} \mathrm{O}_{3}+\mathrm{Ni}+\mathrm{Mo}+\mathrm{Al}_{2} \mathrm{O}_{3}+\mathrm{CaC}_{2}+\mathrm{CaH}_{2}$ & $1150^{\circ} \mathrm{C}, 14 \mathrm{~h}$ \\
\hline 7 & $\mathrm{Cr}_{7} \mathrm{C}_{3}-\mathrm{NiAl}$ & $\mathrm{Cr}_{2} \mathrm{O}_{3}+\mathrm{Ni}+\mathrm{Mo}+\mathrm{Al}_{2} \mathrm{O}_{3}+\mathrm{CaC}_{2}+\mathrm{CaH}_{2}$ & $1150^{\circ} \mathrm{C}, 14 \mathrm{~h}$ \\
\hline
\end{tabular}

data from $X$-ray phase analysis attests that their composition is close to the stoichiometric one.

\subsubsection{Composite metal carbide powders [4]}

When obtaining metal carbide powders by calcium hydride method, calcium carbide is introduced into the initial charge in the amount that is determined taking into account the production of the rated metal carbide. After heat treatment at a temperature of $1150-1200{ }^{\circ} \mathrm{C}$ for up to 20 hours, the reaction products are subjected to a standard hydrometallurgical processing.

In [4, 98], the alloys based on nickel and iron and promising for the use as coatings and binders of hard alloys, were selected for the production of composite metal carbide powders, the particles of which are dispersion reinforced refractory carbides of rare metals.

The charge and modes of obtaining experimental composite metal carbide powders, their chemical, phase composition and some properties are given in Tables 10-12 [4]. All the powders were characterized by a complex, spongy structure of the particles.

\section{Conclusions}

Calcium thermal reduction along with magnesium thermal reduction are mainly meant for manufacturing of rare metals and represent one of the primary

Table 11

Chemical and phase composition of carbide-containing experimental composite powders

\begin{tabular}{|c|c|c|c|c|c|c|c|c|c|c|c|c|}
\hline \multirow{2}{*}{ No. } & \multirow{2}{*}{ Material designation } & \multicolumn{10}{|c|}{ Chemical composition, wt\% } & \multirow{2}{*}{ Phase composition, wt\% } \\
\hline & & $\mathrm{Ti}$ & $\mathrm{Cr}$ & $C_{\text {tot }}$ & $C_{\mathrm{fr}}$ & $\mathrm{Fe}$ & $\mathrm{Ni}$ & Mo & $\mathrm{Al}$ & $\mathrm{Ca}$ & 0 & \\
\hline 1 & $\mathrm{TiC}-\mathrm{Fe}(\mathrm{Ni}, \mathrm{Mo})$ & base & - & 13.9 & 0.04 & 23.5 & 5 & 1.5 & - & 0.1 & 0.2 & $\mathrm{TiC} \sim 70 ; \mathrm{Fe}(\mathrm{Ni}, \mathrm{Mo}) \sim 30$ \\
\hline 2 & $\left(\mathrm{Cr}_{3} \mathrm{C}_{2}+\mathrm{Cr}_{7} \mathrm{C}_{3}\right)-\mathrm{Ni}$ & - & base & 9.5 & 0.02 & 0.2 & 29.3 & - & - & 0.1 & 0.3 & $\mathrm{Cr}_{3} \mathrm{C}_{2}+\mathrm{Cr}_{7} \mathrm{C}_{3} \sim 70 ; \mathrm{Ni} \sim 30$ \\
\hline 3 & $\mathrm{TiC}-\mathrm{Ni}(\mathrm{Mo})$ & base & - & 15.8 & 0.03 & 0.1 & 15.9 & 5.1 & - & 0.1 & 0.1 & $\mathrm{TiC} \sim 80 ; \mathrm{Ni}(\mathrm{Mo}) \sim 20$ \\
\hline 4 & $\left(\mathrm{Cr}_{7} \mathrm{C}_{3}+\mathrm{TiC}\right)-\mathrm{Ni}(\mathrm{Mo})$ & base & 19.0 & 14.0 & 0.06 & 0.3 & 17.3 & 8.0 & - & 0.1 & 0.2 & $\begin{array}{l}\text { Double carbide } \mathrm{Cr}_{7} \mathrm{C}_{3} / \mathrm{TiC}+ \\
+\mathrm{Cr}_{7} \mathrm{C}_{3} \sim 70 ; \mathrm{Ni}(\mathrm{Mo}) \sim 30\end{array}$ \\
\hline 5 & $\mathrm{TiC}-\mathrm{Ni}_{3} \mathrm{Al}$ & base & - & 14.4 & 0.05 & 0.1 & 20.6 & 4.3 & 3.2 & 0.1 & 0.2 & $\mathrm{TiC} \sim 70 ; \mathrm{Ni}_{3} \mathrm{Al} \sim 30$ \\
\hline 6 & $\mathrm{Cr}_{7} \mathrm{C}_{3}-\mathrm{Ni}_{3} \mathrm{Al}$ & - & base & 6.3 & 0.06 & 0.2 & 25.9 & 0.3 & 3.5 & 0.1 & 0.2 & $\mathrm{Cr}_{7} \mathrm{C}_{3} \sim 70 ; \mathrm{Ni}_{3} \mathrm{Al} \sim 30$ \\
\hline 7 & $\mathrm{Cr}_{7} \mathrm{C}_{3}-\mathrm{NiAl}$ & - & base & 7.2 & 0.04 & 0.1 & 13.4 & 0.1 & 6.2 & 0.1 & 0.1 & $\mathrm{Cr}_{7} \mathrm{C}_{3} \sim 70 ; \mathrm{NiAl} \sim 30$ \\
\hline
\end{tabular}


Table 12.

Physical and processing behavior of experimental carbide-containing composite powders

\begin{tabular}{|c|l|c|c|c|}
\hline No. & Material designation & $\begin{array}{c}\text { Particle } \\
\text { size, } \mu \mathrm{m}\end{array}$ & $\begin{array}{c}\text { Specific } \\
\text { surface, } \mathrm{m}^{2} / \mathrm{g}\end{array}$ & $\begin{array}{c}\text { Bulk density, } \\
\mathrm{g} / \mathrm{cm}^{3}\end{array}$ \\
\hline 1 & $\mathrm{TiC}-\mathrm{Fe}(\mathrm{Ni}, \mathrm{Mo})$ & $\leq 10$ & 4.62 & 1.18 \\
\hline 2 & $\left(\mathrm{Cr}_{3} \mathrm{C}_{2}+\mathrm{Cr}_{7} \mathrm{C}_{3}\right)-\mathrm{Ni}$ & $\leq 20$ & 1.06 & 1.33 \\
\hline 3 & $\mathrm{TiC}_{-} \mathrm{Ni}(\mathrm{Mo})$ & $\leq 10$ & 3.54 & 1.07 \\
\hline 4 & $\left(\mathrm{Cr}_{7} \mathrm{C}_{3}+\mathrm{TiC}\right)-\mathrm{Ni}(\mathrm{Mo})$ & $\leq 10$ & 1.64 & 1.31 \\
\hline 5 & $\mathrm{TiC}_{-} \mathrm{Ni}_{3} \mathrm{Al}$ & $\leq 20$ & 1.15 & 1.24 \\
\hline 6 & $\mathrm{Cr}_{7} \mathrm{C}_{3}-\mathrm{Ni}{ }_{3} \mathrm{Al}$ & $\leq 20$ & 0.98 & 1.26 \\
\hline 7 & $\mathrm{Cr}_{7} \mathrm{C}_{3}-\mathrm{NiAl}$ & $\leq 20$ & 1.21 & 1.21 \\
\hline
\end{tabular}

\section{References}

1. Kroll W. J. Method for Manufacturing Titanium and Alloys Thereof. US Patent. 2205854, 1940.

2. Kroll W. J. Transactions of The Electrochemical Society. Vol. 78, Iss. 1. pp. 35-47. DOI: 10.1149/ 1.3071290

3. Jacob K. T., Gupta S. JOM. 2009. Vol. 61, Iss. 5. pp. 56-59. DOI: 10.1007/s11837-009-0072-0

4. Kasimtsev A. V., Levinsky Yu. V. CalciumHydride Powders of Metals, Intermetallic Compounds, refractory compounds and composite materials. Moscow : MITKhT, 2012. 247 p.

5. Meerson G. A., Katz G. A., Khokhlova A. V. Zhurnal Neorganicheskoy i Prikladnoy Khimii. 1940. Vol. 13, No. 12. pp. 1770-1776.

6. Chen G. Z., Fray D. J., Farthing T. W. Nature. 2000. Vol. 407, Iss. 6802. pp. 361-364. DOI: 10.1038/35030069

7. Jiang K., Hu X., Ma M., Wang D., Qui G., Jin X., Chen G. Z. Angewandte Chemie International Edition. 2006. Vol. 45, Iss. 3. pp. 428-432. DOI: 10.1002/anie.200502318

8. Li Wei, Wong Ying, Tang Ren-Heng, Xiao Fang-Ming. Materials Research and Application. 2010. Vol. 4, Iss. 4. pp. 555-558.

9. Katsutoshi Ono, Ryosuke O. Suzuki. JOM. 2002. Vol. 54, Iss. 2. pp. 59-61. DOI: 10.1007/bf02701078

10. Katsutoshi Ono. Materials Transactions. 2004. Vol. 45, Iss. 5, pp. 1660-1664. DOI: 10.1007/bf02701078

11. Moxson V. S., Senkov O. N., Froes F. H. JOM. 2000. Vol. 52, Iss. 5. pp. 24-26. DOI: 10.1007/s11837-000-0027-y

12. He-Li Wan, Bao-Qiang Xu, Yong-Nian Dai, Bin Yang, Da-Chun Liu, Wei Sen. Journal of Central South University. 2012. Vol. 19, Iss. 9. pp. 2434-2439. DOI: 10.1007/s11771-012-1293-X

13. Okabe T. H., Sadoway D. R. Journal of Materials Research. 1998. Vol. 13, Iss. 12. pp. 3372-3377. DOI: 10.1557/ jmr.1998.0459

14. Okabe T. H., Uda T. Titanium Japan. 2002. Vol. 50. pp. $325-330$.

15. Bayat O., Khavandi A. R., Ghasemzadeh R. International Journal of Self-Propagating High-Temperature Synthesis. 2012. Vol. 21, Iss. 3. pp. 151-155. DOI: 10.3103/s1061386212030028

16. Okabe T. H., Oda T., Mitsuda Y. Journal of Alloys and Compounds. 2004. Vol. 364, Iss. 1-2. pp.156-163. DOI: 10.1016/ s0925-8388(03)00610-8

17. Suzuki R. O., Ikezawa M., Okabe T. H., Oishi T., Ono K. Materials Transactions, JIM. 1990. Vol. 31, Iss. 1. pp. 61-68. DOI: $10.2320 /$ matertrans 1989.31.61

18. Yamaguchi K., Kim D.-Y., Ohtsuka M., Itagaki K. Journal of Alloys and Compounds. 1995. Vol. 221, Iss. 1-2. pp. 161168. DOI: 10.1016/0925-8388(94)01422-1

19. Tanabe T., Takahashi K., Yoshida H., Asaki Z. Materials Transactions, JIM. 1994. Vol. 35, Iss. 8. pp. 516-521. DOI: 10.2320/matertrans1989.35.516

20. Tanabe T., Nagai Y., Kubota T., Asaki Z. Materials Transactions, JIM. 1992. Vol. 33, Iss. 12. pp. 1163-1170. DOI: 10.2320/matertrans 1989.33.1163

21. Suzuki R. O., Inoue S. Metallurgical and Materials Transactions: B. 2003. Vol. 34, Iss. 3. pp. 277-285. DOI: 10.1007/ s11663-003-0073-2 
22. Liu S. F., Lin J. H., Qian X. L., Bayi J. M., Su M. Z. Chemistry of Materials. 1996. Vol. 8, Iss. 11. pp. 2545-2547. DOI: $10.1021 / \mathrm{cm} 950513 \mathrm{i}$

23. Mukherjee T. K., Kamat G. R., Gupta C. K. JOM. 1970. Vol. 22, Iss. 2. pp. 50-53. DOI: 10.1007/bf03355939

24. Li Z., Yasuda K., Itagaki K. Journal of Alloys and Compounds. 1993. Vol. 193, Iss. 1-2. pp. 26-28. DOI: 10.1016/09258388(93)90299-3

25. Ilayaraja M., Berchmans L. J., Sankaranarayanan S. R. Metallurgical and Materials Engineering. 2014. Vol. 20, Iss. 1. pp. 35-40. DOI: 10.5937/metmateng1401035i

26. Guilherme E. da G., Hechenberg H. R., Pascoal J. O. A. Materials Science Forum. 2006. Vol. 530-531. pp. 181-186. DOI: 10.4028/www.scientific.net/msf.530-531.181

27. Chen C.-Q., Kim D., Choi C. Journal of Magnetism and Magnetic Materials. 2014. Vol. 355. pp. 180-183. DOI: 10.1016/j.jmmm.2013.12.023

28. Ilayaraja M., Berchmans L. J., Sankaranarayanan S. R. Metallurgical and Materials Engineering. 2015. Vol. 21, Iss. 2 pp. 65-72. DOI: 10.30544/96

29. Chen H.-B., Zheng J.-W., Qiao L., Ying Y., Jiang L.-Q., Che S.-L. Rare Metals. 2015. Vol. 37, Iss. 11. pp. 989-994. DOI: $10.1007 / \mathrm{s} 12598-015-0584-4$

30. Travessini D., Favero T. A. C., Teixeira C. S., Wendhausen P. A. P. IEEE Transactions on Magnetics. 2013. Vol. 49, Iss. 8. pp. 4634-4637. DOI: 10.1109/tmag.2013.2258141

31. Deng G., Jing Q., Wang X., He G., Ye X. Journal of Rare Earths. 2010, Vol. 28. pp. 420-424. DOI: 10.1016/s10020721(10)60357-2

32. Dzneladze Zh. I., Shchegoleva R. P., Golubeva L. S., et al. Powder Metallurgy of Steels and Alloys. Moscow : Metallurgiya, 1978. 264 p.

33. Meerson G. A., Kolchin O. P. Collected Scientific Papers of the Moscow Institute of Nonferrous Metals and Gold named after M. I. Kalinin. Moscow : Metallurgizdat, 1955. No. 25. pp. 195-208.

34. Levinsky Yu. V. Phase Diagrams of Metals with Gases. Moscow : Metallurgiya, 1975. 296 p.

35. Levinsky Yu. V. Pressure Dependent Phase Diagrams of Binary Alloys. Vol. 1, ASM. Materials Park, OH 44073. 1997, $920 \mathrm{p}$.

36. Levinsky Yu. V. P-T-x Phase Diagrams of Binary Systems. Moscow : Metallurgiya, 1982. 111 p.

37. Kasimtsev A. V., Zhigunov V. V. Izvestiya Vuzov. Poroshkovaya Metallurgiya i Funktsional'nye Pokrytiya. 2009. No. 3. pp. 5-12.

38. Doronin N. A. Calcium. Moscow : Gosatomizdat, 1962. $192 \mathrm{p}$.

39. Bayat O., Khavandi A. R., Ghasemzadeh R. Russian Journal of Non-Ferrous Metals. 2012. Vol. 53, Iss. 6. pp. 476482. DOI: $10.3103 / \mathrm{s} 1067821212060028$

40. Byun J.-Y., Kim Y.-S., Shim J.-D. Shigen-to-Sozai. 1994. Vol. 110, Iss. 15. pp. 1203-1208. DOI: 10.2473/shigentosozai. 110.1203

41. Suzuki R. O., Aizawa M., Ono K. Journal of Alloys and Compounds. 1999. Vol. 288, Iss. 1-2.pp. 173-182. DOI: 10.1016/ s0925-8388(99)00116-4
42. Xu B., Yang B., Jia J., Liu D., Xiong H., Deng Y. Journal of Alloys and Compounds. 2013. Vol. 576. pp. 208-214. DOI: $10.1016 /$ j.jallcom.2013.04.107

43. Suzuki R.O., Ueki T., Ikezawa M., Okabe T. H., Oishi T., Ono K. Materials Transactions, JIM. 1991. Vol. 32, Iss. 3. pp. 272-277. DOI: 10.2320/matertrans1989.32.272

44. Ono K., Okabe T. H., Ogawa M., Suzuki R. O. Tetsu-toHagane. 1990, Vol. 76, Iss. 4. pp. 568-575. DOI: 10.2355/tetsutohagane 1955.76.4_568

45. Levinsky Yu. V., Lebedev M. P. Theoretical Bases Of Metal Powder Sintering Processes. Moscow : Nauchnyi Mir, 2014. 372 p.

46. Geguzin Ya. E. Physics of Sintering. $2^{\text {nd }}$ ed. Moscow : Nauka, 1984. 311 p.

47. Gupta C. K., Jena P. K. Journal of the Less Common Metals. 1965. Vol. 8, Iss. 2. pp. 90-98. DOI: 10.1016/00225088(65)90100-1

48. Suzuki N., Tanaka M., Noguchi H., Natsui S., Kikuchi T. Suzuki R. O. Materials Transactions. 2017. Vol. 58, Iss. 3. pp. 367-370. DOI: 10.2320/matertrans.mk201613

49. Suzuki R. O., Nagai H., Oishi T., Ono K. Journal of Materials Science. 1987. Vol. 22, Iss. 6. pp. 1999-2005. DOI: $10.1007 / \mathrm{bf0} 1132930$

50. Lindemann I., Herrich M., Gebel B., Schmidt R., Stoeck U., Uhlemann M., Gebert A. Scripta Materialia. 2017. Vol. 130, pp. 256-259. DOI: 10.1016/j.scriptamat.2016.11.018

51. Frau D. J. JOM. 2001. Vol. 53. pp. 26-31.

52. Kamali A. R., Aboutalebi M. R., Farhang M. R. International Journal of Self-Propagating High-Temperature Synthesis. 2008. Vol. 17, Iss. 4. pp. 233-236.

53. Oh J.-M., Lee B.-K., Suh C.-Y., Cho S.-W., Lim J.-W. Powder Metallurgy. 2012. Vol. 55, Iss. 5. pp. 402-404. DOI: 10.1179/1743290112y.0000000013

54. Oh J.-M., Kwon H., Ki W., Lim J.-W. Thin Solid Films. 2014. Vol. 551. pp. 98-101. DOI: 10.1016/j.tsf.2013.11.076

55. Kasimtsev A. V., Shuitsev A. V., Yudin S. N., Levinsky Yu. V., Sviridova T. A., Alpatov A. V., Novosvetlova E. E. Metally. 2017. No. 5. pp. 52-63.

56. Sehra J. C., Rakhasia R. H., Shah V. D. High Temperature Materials and Processes. 1997. Vol. 16. pp. 123-132. DOI: 10.1515/htmp.1997.16.2.123

57. Baba M., Kikuchi T., Suzuki R. O. J. Journal of Physics and Chemistry of Solids. 2015. Vol. 78. pp. 101-109. DOI: 10.1016/j. jpcs.2014.11.014

58. Baba M., Ono Y., Suzuki R. O. Journal of Physics and Chemistry of Solids. 2005. Vol. 66, Iss. 2-4. pp. 466-470. DOI: $10.1016 /$ j.jpcs.2004.06.042

59. Niiyama H., Tsukihashi F., Sano N. Journal of Alloys and Compounds. 1992, Vol. 179, Iss. 1-2. pp. L1-L5. DOI: 10.1016/0925-8388(92)90193-d

60. Mukherjee A., Awasthi A., Krishnamurthy N. Mineral Processing and Extractive Metallurgy. 2016. Vol. 125, Iss. 1. pp. 26-31. DOI: 10.1179/1743285515y.0000000017

61. Cupta C. K., Krishramurthy N. Minerals and Metallurgical Processing. 2013. Vol. 30, No. 1, pp. 38-44.

62. Spedding F. H., Daane A. H. JOM. 1954. Vol. 6, Iss. 5. pp. 504-510. DOI: 10.1007/bf03398865 
63. Spedding F. H., Wilhelm H. A., Keller W. H., Ahmann D. H., Daane A. H., Hach C. C., Ericson R. P. Industrial \& Engineering Chemistry. 1952. Vol. 44, Iss. 3. pp. 553-556. DOI: 10.1021/ ie $50507 \mathrm{a} 034$

64. Sharma R.A. JOM. 1987. Vol. 39, Iss. 2. pp. 33-37. DOI: 10.1007/bf03259468

65. Sharma R. A., Seefurth R. N. Journal of The Electrochemical Society. 1988. Vol. 135, Iss. 1. pp. 66-71. DOI: 10.1149/1.2095591

66. Suzuki R. O., Baba M., Yamamoto K. Proc. $7^{\text {th }}$ Int. Symp. on Molten Salts Chem. and Techn. (29 Aug. - 02 Sept. 2005, Toulouse, France). Vol. 2. pp. 1063-1066.

67. Niiyama H., Tajima Y., Tsukihashi F., Sano N. Journal of the Less Common Metals. 1991. Vol. 169, Iss. 2. pp. 209-216. DOI: 10.1016/0022-5088(91)90069-g

68. Suzuki R. O., Ikezawa., Okabe T. H., Oishi T., Ono K. Materials Transactions, JIM. 1990. Vol. 31, Iss. 1. pp. 61-68. DOI: $10.2320 /$ matertrans 1989.31 .61

69. Suzuki R. O., Sakamoto H., Oishi T., Ono K. Proc. $6^{\text {th }}$ World Conf. on Titanium, Cannes, France, 1988. Part II. pp. 895900 .

70. Bertheville B., Bidaux J.-E. Journal of Alloys and Compounds. 2005. Vol. 387, Iss. 1-2. p. 211-216. DOI: 10.1016/j. jallcom.2004.06.079

71. Bertheville B., Bidaux J.-E. Scripta Materialia. 2005. Vol. 52, Iss. 6. pp. 507-512. DOI: 10.1016/j.scriptamat.2004.11.002

72. Kasimtcev A. V., Markova G. V., Shuytcev A. V., Levinsky Yu. V., Sviridova T. A., Alpatov A. V. Izvestiya Vuzov. Poroshkovaya Metallurgiya i Funktsional'nye Pokrytiya. 2014. No. 3. pp. 31-37. DOI: 10.17073/1997-308X-2014-3-31-37

73. Markova G. V., Kasimtsev A. V., Volodko S. S., Bubnenkov B. B. Tsvetnye Metally. 2018. No. 11. pp. 75-82. DOI: 10.17580/tsm.2018.11.11

74. Markova G. V., Kasimtsev A. V., Volodko S. S., Bubnenkov B. B. Tsvetnye Metally. 2018. No. 12. pp. 75-81. DOI: 10.17580/tsm.2018.12.11

75. Bayat O., Khavandi A. R., Ghasemzadeh R. Journal of Alloys and Compounds. 2012. Vol. 520. pp. 164-169. DOI: 10.1016/j.jallcom.2011.12.174

76. Suzuki R. O., Yoshinori M. Joint International Conference on "Sustainable Energy and Environment (SEE)", 1-3 December, 2004. HuaHin, Thailand, pp. 167-170.

77. Tsuchiya T., Yahsuda N., Sasaki S., Okinaka N., Akiyama T. International Journal of Hydrogen Energy. 2013. Vol. 38. pp. 6681-6686. DOI: 10.1016/j.ijhydene.2013.02.106

78. Davids M. W., Lototskyy M., Pollet B. G. Advanced Materials Research. 2013, Vol. 746. pp. 14-22. DOI: 10.4028/www. scientific.net/amr.746.14

79. Okabe T. H., Fujiwara K., Oishi T., Ono K. Metallurgical Transactions B. 1992. Vol. 23, Iss. 4. pp. 415-421. DOI: 10.1007/ bf02649659
80. Kasimtsev A. V., Korneev L. I. Izvestiya Vuzov. Tsvetnaya Metallurgiya. 2002. No. 1. pp. 48-52.

81. Pat. RU 2351534. C1, CO1B 3/56, 6/24. Method for Making Reversible Hydrogen-Sorbing Alloy Combination (Versions). Inventor/Proprietor: Kasimtsev A. V. Application: No. 2007124359/15, 29.06.2007; Publication: 10.04.2009, Bull. No. 10

82. Xiao Y., Liu Y., Yuan D., Zang J., Mi Y. Materials Letters. 2006. Vol. 60, Iss. 21-22. pp. 2558-2560. DOI: 10.1016/j. matlet.2006.01.036

83. Kim C. W., Kim Y. H., Cha H. G., Kang Y. S. Physica Scripta. 2007. Vol. 129. pp. 321-325. DOI: 10.1088/00318949/2007/t129/071

84. Chen C.-Q., Kim D., Choi C. Journal of Magnetism and Magnetic Materials. 2014. Vol. 355. pp. 180-183. DOI: 10.1016/j.jmmm.2013.12.023

85. Sidhu R. K. Journal of Alloys and Compounds. 2002. Vol. 346, Iss. 1-2. pp. 250-254. DOI: 10.1016/s09258388(02)00496-6

86. Gabay A. M., Hu X. C., Hadjipanayis G. C. Journal of Alloys and Compounds. 2013. Vol. 574. pp. 472-476. DOI: 10.1016/j.jallcom.2013.05.155

87. Kasimtsev A. V., Yudin S. N., Logacheva A. I., Sviridova T. A. Neorganicheskiye Materialy. 2015. Vol. 51, No. 1. pp. 49-56.

88. Kasimtsev A. V., Reutova N. P., Mnasina L. M., Zubkov N. P., Sviridova T. A., Turutin Yu. A. Izvestiya Vuzov. Poroshkovaya Metallurgiya i Funktsional'nye Pokrytiya. 2010. No. 3. pp. 3-10.

89. Jacob K. T., Gupta S. Bulletin of Materials Science. 2009. Vol. 2, Iss. 6. pp. 611-616. DOI: 10.1007/s12034-009-0094-9

90. Meerson G. A., Yakisheva L. M., Shvedova T. A. Proceedings of the USSR Academy of Sciences. Metallurgy and Mining. 1963. No. 1. pp. 69-73.

91. Lobova T. A. Izvestiya Vuzov. Tsvetnaya Metallurgiya. 2001. No. 6. pp. 10-17.

92. Bavbande D. V., Mishra R., Juneja J. M. Journal of Thermal Analysis and Calorimetry. 2004. Vol. 78, Iss. pp. 775-780. DOI: 10.1007/s10973-005-0445-0

93. Kotenev V. I., Kasimtsev A. V., Zhigunov V. V., Koteneva V. Ya. Poroshkovaya Metallurgiya. 1988. No. 3. pp. 12-16.

94. Kasimtsev A. V., Zhigunov V. V., Tabachkova N. Yu. Izvestiya Vuzov. Poroshkovaya Metallurgiya i Funktsional'nye Pokrytiya. 2008. No. 4. pp. 15-19.

95. Kasimtsev A. V., Korneev L. I., Zhigunov V. V. Tyazheloe Mashinostroenie. 2006. No. 11. pp. 6-9.

96. Kiparisov S. S., Levinskii Yu.V. Internal Oxidation and Nitriding of Alloys. Moscow : Metallurgiya, 1979. 199 p.

97. Levinskii Yu. V. Internally Oxidized and Internally Nitrided Nanomaterials. Moscow : EKOMET, 2009. 399 p.

98. Kasimtsev A. V., Levinsky Yu. V., Zhigunov V. V. Izvestiya Vuzov. Poroshkovaya Metallurgiya i Funktsional'nye Pokrytiya. 2008. No. 2. pp. 3-8. 